\title{
Acquisition of the neodymium isotopic composition of the North Atlantic Deep Water
}

\author{
Francois Lacan and Catherine Jeandel \\ CNRS, LEGOS, UMR5566, CNRS-CNES-IRD-UPS, Observatoire Midi-Pyrénées, 18, Avenue E. Belin, F-31400 \\ Toulouse, France (francois.lacan@cnes.fr)
}

[1] The North Atlantic Deep Water (NADW) neodymium isotopic composition (Nd IC) is increasingly used in oceanography and paleoceanography to trace large-scale circulation and weathering processes, notably to investigate past variations of the global thermohaline circulation. Although the present-day NADW Nd IC is well characterized at $\varepsilon_{\mathrm{Nd}}=-13.5$, the acquisition of this isotopic signature (in other words, the causes of this value) has so far been very sparsely documented. Such an understanding is, however, fundamental to the interpretation of paleo records. Nd IC and rare earth element concentrations were measured at 9 stations within the North Atlantic Subpolar Gyre (SIGNATURE cruise, summer 1999). The comparison of this data set with our understanding of water mass circulation provides a description of how the three layers constituting the NADW, the Labrador Sea Water (LSW, $\varepsilon_{\mathrm{Nd}}=-13.9 \pm 0.4$ ), North East Atlantic Deep Water (NEADW, $\varepsilon_{\mathrm{Nd}}-13.2 \pm 0.4$ ), and North West Atlantic Bottom Water (NWABW, $\varepsilon_{\mathrm{Nd}}-14.5 \pm 0.4$ ), acquire their Nd IC through distinct water mass mixings and lithogenic inputs. These different mechanisms, acting upon water masses from very diverse sources, seem to bring the Nd IC of the three NADW layers to values close together and similar to that of the NADW. It is suggested that sediment/seawater interactions significantly lower the NEADW and NWABW Nd IC along the South East Greenland margin. Since these interactions do not significantly modify the $\mathrm{Nd}$ content of these water masses, sediment remobilizations leading to the Nd IC variations are probably associated with $\mathrm{Nd}$ removal fluxes from the water mass toward the sediment, a process called boundary exchange. On the other hand, LSW seems to acquire its Nd IC from the Subpolar Mode Waters from which it is formed by deep convection, and no other mechanism needs to be invoked. Its unradiogenic signature could ultimately be linked to fresh water runoff from the Canadian Shield. These conclusions should allow more precise interpretations of paleoceanographic Nd IC records, taking into account the distinct histories of the three NADW layers, including distinct water mass mixings and distinct lithogenic inputs.

Components: 12,506 words, 6 figures, 4 tables.

Keywords: boundary exchange; neodymium isotopic composition; North Atlantic Deep Water; rare earth elements; sediment seawater interaction; water mass.

Index Terms: 1050 Geochemistry: Marine geochemistry (4835, 4845, 4850); 4825 Oceanography: Biological and Chemical: Geochemistry; 4999 Paleoceanography: General or miscellaneous.

Received 31 March 2005; Revised 9 September 2005; Accepted 4 November 2005; Published 30 December 2005.

Lacan, F., and C. Jeandel (2005), Acquisition of the neodymium isotopic composition of the North Atlantic Deep Water, Geochem. Geophys. Geosyst., 6, Q12008, doi:10.1029/2005GC000956.

\section{Introduction}

[2] The neodymium isotopic composition (Nd IC) is expressed as $\varepsilon_{\mathrm{Nd}}$, defined by

$$
\varepsilon_{\mathrm{Nd}}=\left(\frac{\left(\frac{143 \mathrm{Nd}}{(144 \mathrm{Nd}}\right)_{\mathrm{Sample}}}{\left(\frac{143 \mathrm{Nd}}{144 \mathrm{Nd}}\right)_{\mathrm{CHUR}}}-1\right) \times 10^{4}
$$


where CHUR stands for Chondritic Uniform Reservoir and represents a present-day average earth value: $\left({ }^{143} \mathrm{Nd} /{ }^{144} \mathrm{Nd}\right)_{\mathrm{CHUR}}=0.512638$ [Jacobsen and Wasserburg, 1980]. The Nd IC of the continents is heterogeneous, varying from $\varepsilon_{\mathrm{Nd}} \approx$ -45 in old granitic cratons to $\varepsilon_{\mathrm{Nd}} \approx+12$ in recent mid-oceanic ridge basalts [Goldstein and Hemming, 2003]. In the ocean, $\mathrm{Nd}$ is a trace element of lithogenic origin (concentrations of the order of $10^{-12} \mathrm{~g} \mathrm{~g}^{-1}$ ), predominantly found in its dissolved form (90 to 95\%) [Jeandel et al., 1995]. Through lithogenic inputs, different water masses acquire different Nd IC. $\varepsilon_{\mathrm{Nd}}$ can therefore be used to quantify dissolved/particulate fluxes, notably along continental margins [Tachikawa et al., 1999a, 2004]. Away from those inputs, $\varepsilon_{\mathrm{Nd}}$ behaves conservatively in the ocean [Piepgras and Wasserburg, 1987; Piepgras and Jacobsen, 1988; Jeandel, 1993; Goldstein and Hemming, 2003; Lacan and Jeandel, 2004c]. Indeed, Nd removal processes and evaporation modify $\mathrm{Nd}$ concentrations in seawater but not $\varepsilon_{\mathrm{Nd}}$. Nd oceanic residence time is around 500 to 1000 years [Tachikawa et al., 2003], slightly less than the oceanic mixing time. The oceanic Nd IC distribution is therefore mostly governed by the thermohaline circulation. It is heterogeneous, varying from about -25 in the extreme northwest Atlantic (Baffin Bay-Labrador Sea) to about 0 in the North Pacific [Stordal and Wasserburg, 1986] (see compilation by Lacan and Jeandel [2005]). $\varepsilon_{\mathrm{Nd}}$ is thus used as a water mass tracer in the modern ocean [e.g., Piepgras and Wasserburg, 1980; Jeandel, 1993; Amakawa et al., 2004].

[3] Nd belongs to the geochemical group of Rare Earth Elements (REE). In the ocean, particle scavenging and cerium oxidation cause a heavy versus light REE enrichment and a negative Ce anomaly respectively, relative to the lithogenic sources [Elderfield, 1988]. These fractionations are quantified by normalizing the oceanic concentrations to a lithogenic reference material: in this work, the Post-Archean Australian Sedimentary Shales (PAAS) [Taylor and McLennan, 1985]. They can be expressed by the $\mathrm{La}_{\mathrm{n}} / \mathrm{Yb}_{\mathrm{n}}$ ratio and the $\mathrm{Ce}$ anomaly, $\mathrm{Ce} / \mathrm{Ce}^{*}=\mathrm{Ce}_{\mathrm{n}} /\left[\left(\mathrm{La}_{\mathrm{n}}+\operatorname{Pr}_{\mathrm{n}}\right) / 2\right]$, where the subscript " $n$ " indicates that the concentrations are normalized (e.g., $X_{n}=X_{\text {sample }} \times 10^{6} / X_{\text {PAAS }}$ ). These parameters are a useful tool for studying dissolved/particulate interactions in seawater and notably for identifying recent lithogenic inputs [Elderfield, 1988; Tachikawa et al., 1999b]. The closer to 1 these parameters are, the smaller the anomalies are, i.e., the closer to a lithogenic sample the seawater sample is.
[4] The Nd IC is increasingly used in paleoceanography. The seawater Nd IC recorded in different carrier phases such as ferromanganese crust and nodules, fish teeth or foraminifera tests, is used to reconstruct past changes in oceanic circulation and erosion, over different timescales [e.g., Staudigel et al., 1985; Albarède and Goldstein, 1992; Vance and Burton, 1999]. Studies of past fluctuations of the global thermohaline circulation are limited by the uncertainty of the past $\mathrm{Nd}$ isotopic signature of North Atlantic Deep Water (NADW) [e.g., Rutberg et al., 2000; Frank et al., 2002; Piotrowski et al., 2004, 2005].

[5] However, the acquisition of the present-day NADW Nd IC of $\approx-13.5$ [Piepgras and Wasserburg, 1987; von Blanckenburg and Nägler, 2001] has been sparsely documented until now. The only works reporting seawater Nd IC data in the NADW formation area (the North Atlantic Subpolar Gyre, located north of $50^{\circ} \mathrm{N}$ ) are Stordal and Wasserburg [1986] and Piepgras and Wasserburg [1987]. The former reports data from Baffin Bay and one station at the northern end of the Labrador Sea. The latter reports about twenty data north of $50^{\circ} \mathrm{N}$, spread over the North Atlantic Subpolar Gyre and the Nordic Seas (north of the Greenland Scotland gap). Nonetheless, these studies determined that the dense waters overflowing the Greenland Scotland gap were characterized by an $\mathrm{Nd}$ IC of around -8 and that waters flowing along the Labrador margin had much more negative Nd IC: around -20 . The NADW Nd IC was therefore interpreted as resulting from these two contributions. However, due to the limited data set, Piepgras and Wasserburg [1987] were unable to quantify the mixing of these two end-members and limited their conclusion about this issue to "Mixtures of these overflow waters with the more negative $\varepsilon_{\mathrm{Nd}}$ values associated with Labrador Sea and Baffin Bay sources could, in principle, yield the isotopic signature of NADW." Moreover, although these authors described the negative signatures of the Baffin and Labrador Sea Waters as resulting from lithogenic inputs from the Greenland, Baffin and Labrador formations, they could not investigate the features and locations of these inputs nor how they affect the different water masses.

[6] Owing to the fact that (1) the NADW represents the negative $\varepsilon_{\mathrm{Nd}}$ end-member of the principal world ocean water masses and (2) the NADW Nd IC is increasingly used in modern and paleo oceanography, it is important to improve our un- 


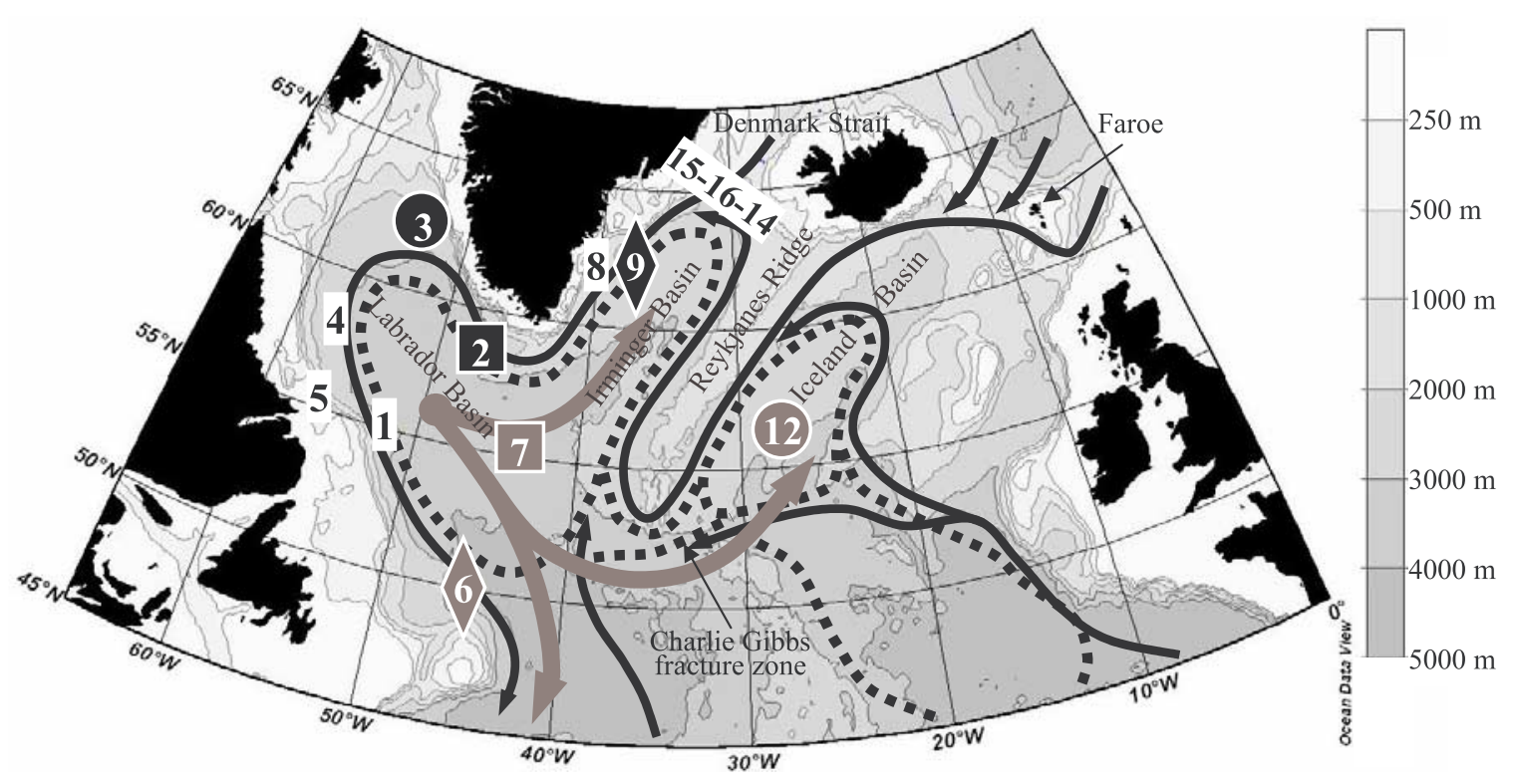

Figure 1. Map of the studied area. Isolines show the topography. Sampling sites are represented by different symbols and identified by station numbers. The black and gray symbols identify stations whose properties are plotted in Figure 3 (symbols in both figures correspond). The black unbroken arrows represent bottom flows (DEBC, Deep Eastern Boundary Current; DNBC, Deep Northern Boundary Current; DWBC, Deep Western Boundary Current). Dotted lines represent deep recirculation cells. The gray arrows represent the main LSW propagation directions. Map created with the Ocean Data View Software (R. Schlitzler, Ocean Data View, 2004; available at http://www.awibremerhaven.de/GEO/ODV).

derstanding of the present-day NADW Nd IC acquisition. This was the purpose of the SIGNATURE program carried out in the North Atlantic Subpolar Gyre and the Nordic Seas, in summer 1999. The results obtained in the Nordic Seas are described in two other articles [Lacan and Jeandel, 2004a, 2004b]. These studies showed evidence that the relatively radiogenic signatures of the waters overflowing the Greenland Iceland gap (Denmark Strait Overflow Water), $\varepsilon_{\mathrm{Nd}}=-8.4 \pm 1.4$, and the Iceland Scotland gap (Iceland Scotland Overflow Water), $\varepsilon_{\mathrm{Nd}}=-8.2 \pm 0.6$, reflect the imprint of the surrounding basaltic formations (characterized by $\varepsilon_{\mathrm{Nd}}$ values around +7 ) on more unradiogenic waters originating from the Nordic Seas, via sediment seawater interactions. The results obtained in the upper $1000 \mathrm{~m}$ of the North Atlantic Subpolar Gyre are described by Lacan and Jeandel [2004c] and summarized further on. The present article presents new data obtained in the deep layers $(>1000 \mathrm{~m}$ depth) of the North Atlantic Subpolar Gyre. It describes how the water masses directly involved in the NADW formation acquire their Nd IC.

\section{Hydrographic Context}

[7] The studied area covers the Subpolar North Atlantic region (see Figure 1). Its hydrography is complex. On the one hand, warm and saline subtropical waters merge with cold and fresh polar waters within the upper layers, leading to numerous transformations and mixing, notably deep convection processes. On the other hand, dense waters formed by such convection at high latitudes merge and mix within deep cyclonic recirculation gyres significantly constrained by an uneven topography. The water mass abbreviations used below are summarized in Table 1.

[8] The deep and intermediate flows are schematized in Figure 1. They mainly consist of the following:

[9] 1. The Deep Eastern Boundary Current (DEBC), traceable from the Iberian Basin, notably carrying waters from the southern hemisphere;

[10] 2. The Deep Northern Boundary Current (DNBC), following on from the DEBC, which first integrates waters overflowing the Iceland-Scotland ridge, then flows round the Reykjanes ridge through the Charlie Gibbs fracture zone ( $3600 \mathrm{~m}$ deep), then integrates the waters overflowing the Denmark Strait, before flowing round the southern tip of Greenland (Cape Farewell) and entering the Labrador Basin; 
Table 1. Abbreviations of Water Mass Names

\begin{tabular}{|c|c|}
\hline Abbreviations & Full Names \\
\hline DSOW & Denmark Strait Overflow Water \\
\hline ISOW & Iceland Scotland Overflow Water \\
\hline LDW & Lower Deep Water \\
\hline LSW & Labrador Sea Water \\
\hline NADW & North Atlantic Deep Water \\
\hline NEADW & North East Atlantic Deep Water \\
\hline NWABW & North West Atlantic Bottom Water \\
\hline pISOW & pure Iceland Scotland Overflow Water \\
\hline SPMW & Subpolar Mode Water \\
\hline
\end{tabular}

[11] 3. The Deep Western Boundary Current (DWBC) following on from the DNBC, which incorporates the deep waters of the Labrador Basin, and flows on southward, down to the Southern Ocean.

[12] 4. A deep northward flow also occurs along the western side of the Mid-Atlantic Ridge, notably carrying waters from the southern hemisphere to the Irminger Basin.

[13] 5. Finally, deep cyclonic recirculating gyres are found on both sides of the Mid-Atlantic Ridge. These are connected above $3600 \mathrm{~m}$ depth through the Charlie Gibbs fracture zone [McCartney, 1992; Dickson and Brown, 1994; Read, 2001].

[14] The main water masses carried by these currents are described below. Their hydrographical properties are displayed in Figures 2 and 3.

[15] 1. The Labrador Sea Water (LSW) formed by deep convection in the Labrador Basin. It is easily identifiable by sharp local salinity minimum and oxygen maximum, at density $\sigma_{\theta} \approx 27.775 \mathrm{~kg} \mathrm{~m}^{-3}$ $(\approx 1650 \mathrm{~m}$ depth; see Figure 3$)$. It is found throughout the North Atlantic Subpolar gyre, its main propagation directions being schematized in Figure 1. The LSW can be considered as the densest variety of the Subpolar Mode Water (SPMW); the SPMW resulting from the mixing of subtropical and polar waters within the Subpolar Gyre, of which it occupies most of the first $1000 \mathrm{~m}$ [McCartney and Talley, 1982; Talley and McCartney, 1982; Talley, 1999].

[16] 2. The Lower Deep Water (LDW) originates as Antarctic Bottom Water (AABW), which flows up the entire Atlantic Ocean and whose characteristics are significantly modified along the way by mixing with other water masses, notably NADW. The LDW is identifiable by a silicate maximum and an oxygen minimum. It enters the Subpolar North Atlantic region, from the East, within the
Deep Eastern Boundary Current, off the European coast, and from the West, flowing along the western side of the Mid-Atlantic Ridge. A distinction is therefore made between the eastern and western LDW. Both LDW mix with waters overflowing the Greenland Scotland gap, within the deep recirculating gyres [McCartney, 1992; Dickson and Brown, 1994].

[17] 3. Dense waters overflow the Iceland Scotland gap. For $\sigma_{\theta}>27.80 \mathrm{~kg} \mathrm{~m}^{-3}$, the flow is $\sim 1 \mathrm{~Sv}$ $\left(1 \mathrm{~Sv}=10^{6} \mathrm{~m}^{3} \mathrm{~s}^{-1}\right)$ above the Iceland Faroe ridge (sill depth of $480 \mathrm{~m}$ ) and $\sim 1.5 \mathrm{~Sv}$ through the Faroe Bank channel (between Faroe and Scotland, sill depth of $840 \mathrm{~m}$; see Figure 1). Due to their high density, these waters sink toward the bottom of the
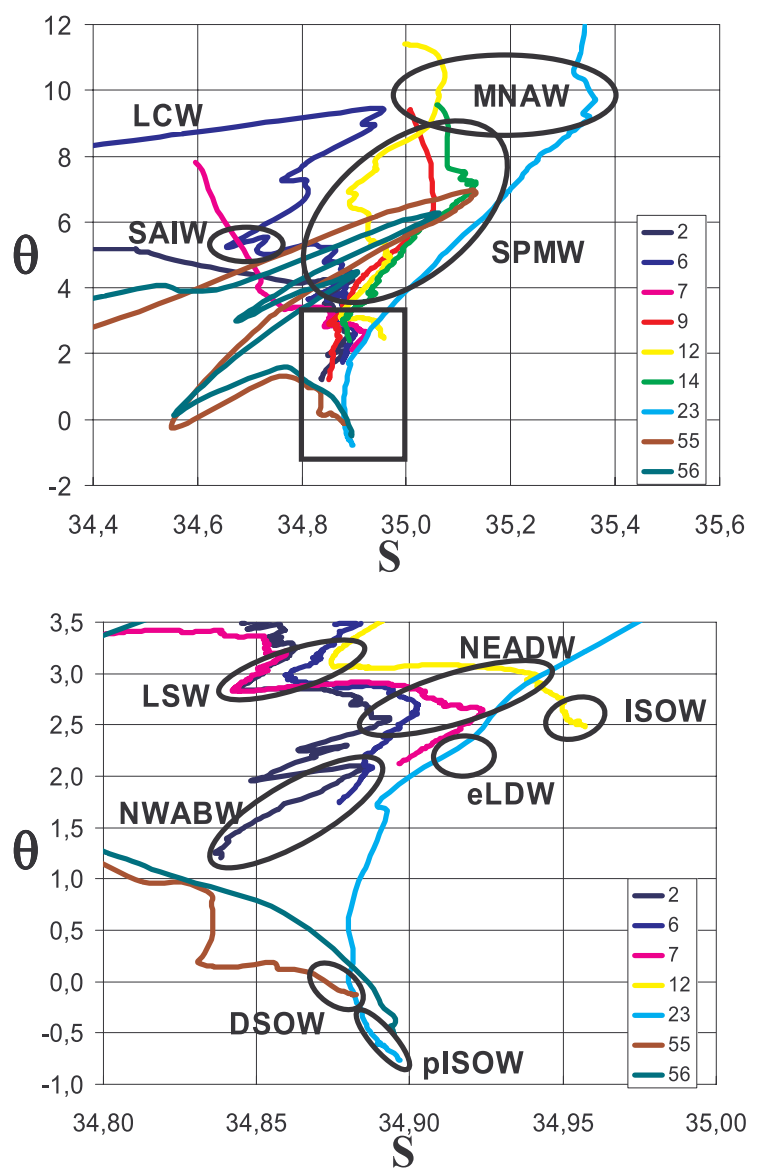

Figure 2. Potential temperature versus salinity diagrams indicating the properties of the different water masses discussed in the text. The bottom panel is a zoom on the area indicated by a rectangle in the top panel. Data from the SIGNATURE cruise. Note that data from some stations not represented in Figure 1 are displayed in order to show the properties of source waters (such as DSOW or pISOW; station 23 is located in the Faeroe-Shetland Channel, and stations 55 and 56 are located in the Denmark Strait). 

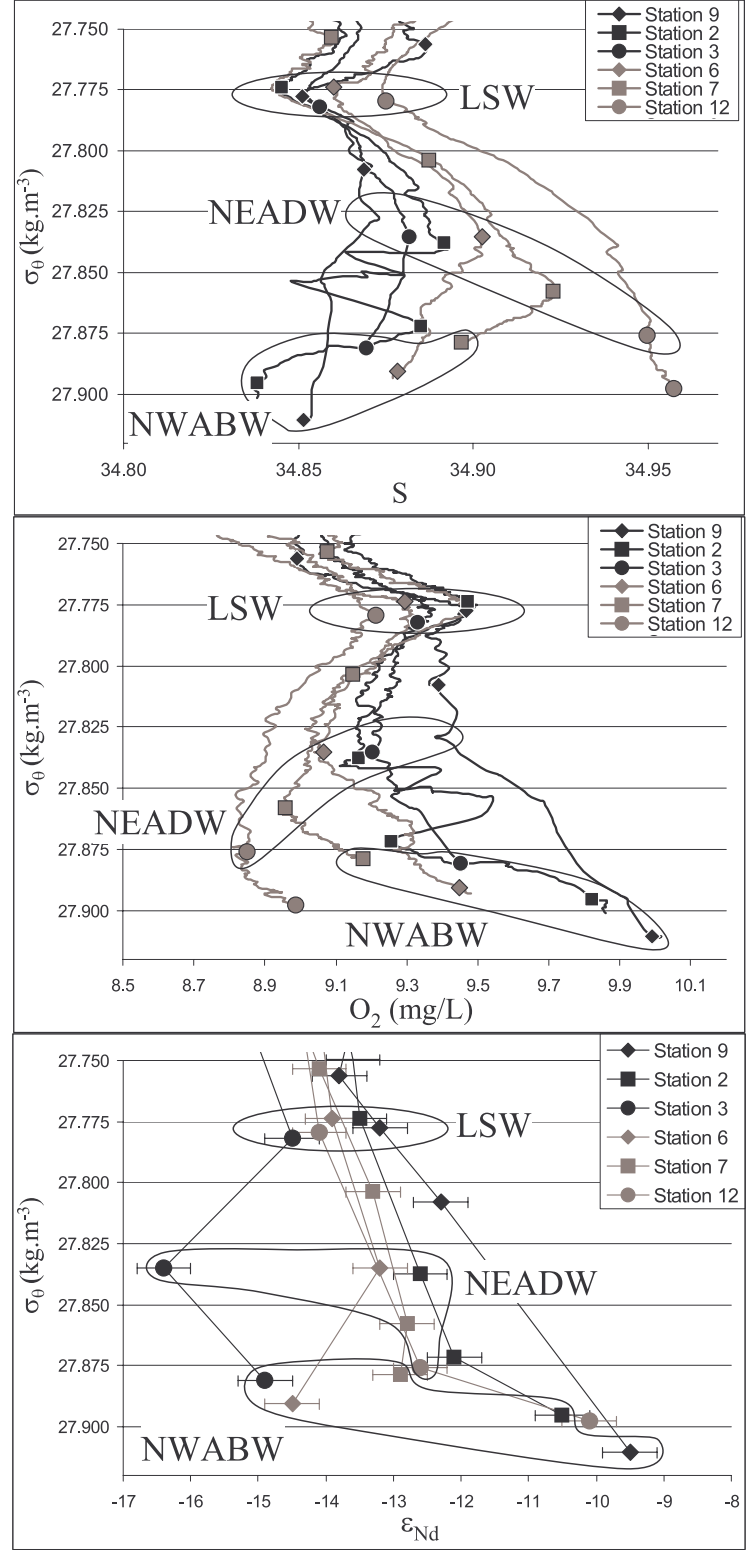

Figure 3. Salinity (S), dissolved oxygen concentration $\left(\mathrm{O}_{2}\right)$, and $\varepsilon_{\mathrm{Nd}}$ as a function of potential density $\left(\sigma_{\theta}\right)$ in the deep layers, at the stations displayed by black and gray symbols in Figure 1 (symbols in both figures correspond). Samples characterizing the three protoNADW layers are indicated.

Iceland Basin, entraining the surrounding waters: Modified North Atlantic Water (a water mass whose high temperature and salinity originate from the Subtropical Atlantic) and LSW. The thusformed water mass is named Iceland Scotland Overflow Water (ISOW) [Hansen and Østerhus, 2000]. However, the use of this term in the literature is particularly ambiguous, since some works also use it to describe the overflowing waters prior to the above mentioned entrainments. This distinction is important since these entrainments considerably modify the hydrographical properties of the overflowing waters, significantly increasing their temperature and salinity. In this paper, the name "pure ISOW" (pISOW) will be used to distinguish the overflowing waters before the entrainments.

[18] 4. Part of the ISOW then flows within the Deep Northern Boundary Current into the Irminger Basin, whereas another part remains on the eastern side of the Mid-Atlantic Ridge, where it recirculates in the Iceland and West European Basins. Within the deep recirculating gyres of these basins (in particular east of the Mid-Atlantic Ridge), the ISOW significantly mixes with the surrounding water masses, notably LSW and LDW. This leads to the formation of the North East Atlantic Deep Water (NEADW). This water mass is characterized by a salinity maximum (due to the Modified North Atlantic Water entrainment) and an oxygen minimum (due to the mixing with LDW) at density $\sigma_{\theta} \approx 27.85 \mathrm{~kg} \mathrm{~m}^{-3}(\approx 2500 \mathrm{~m}$ depth; see Figure 3$)$. Throughout the North Atlantic Subpolar Gyre, the NEADW is found below the LSW and above the bottom waters [Swift, 1984; McCartney, 1992; Dickson and Brown, 1994; Hansen and Østerhus, 2000; Fleischmann et al., 2001; Read, 2001].

[19] 5. A dense water mass also overflows the Denmark Strait (Denmark Strait Overflow Water: DSOW). Its flux is approximately $3 \mathrm{~Sv}$ for $\sigma_{\theta}>$ $27.80 \mathrm{~kg} \mathrm{~m}^{-3}$. Just downstream of the Denmark Strait (sill depth of $630 \mathrm{~m}$ ), it sinks down to the bottom of the Irminger Basin (depth of the order of 2000 to $3000 \mathrm{~m}$ ) entraining significant amounts of surrounding waters, the LSW and the SPMW.

[20] 6. These entrainments lead to the formation of the North West Atlantic Bottom Water (NWABW). This water mass is the densest of the Irminger and Labrador Basins. It is too dense to enter the Iceland Basin through the Charlie Gibbs fracture zone. It is identifiable in Figure 3 by local salinity minimum and oxygen maximum at the bottom. [Swift, 1984; McCartney, 1992; Dickson and Brown, 1994; Schmitz, 1996]. The contribution of LDW is thought to occur around $50^{\circ} \mathrm{N}(1 \mathrm{~Sv})$ and $30^{\circ} \mathrm{N}$ $(1 \mathrm{~Sv})$, in which case it is unlikely to be significant in the studied area [Schmitz, 1996].

[21] Note that Baffin Bay waters overflowing the Davis Strait are not dense enough to directly contribute to the intermediate and deep Labrador Sea Water masses. Their influence is restricted to 
the Labrador Current flowing within the surface layer along the Labrador coast. Therefore their very negative $\varepsilon_{\mathrm{Nd}}$ values do not affect the NADW signature directly, but only indirectly through their involvement in deep water formation (mostly LSW formation).

[22] The formation of the NADW is sparsely documented in terms of water masses, most of the studies treating the topic mainly in terms of currents and transports. However, Schmitz [1996] reviewed this issue in detail. The NADW is identifiable by a salinity maximum around 2000 to $3000 \mathrm{~m}$ depth, from the North to the South of the Atlantic Ocean. It can be divided into three layers: the Lower, Middle and Upper NADW. Schmitz [1996] schematically summarized the composition of the NADW as follows:

[23] 1. $8 \mathrm{~Sv}$ LowerNADW composed of $3 \mathrm{~Sv}$ DSOW, $3 \mathrm{~Sv}$ of entrained subpolar waters (LSW and SPMW) and $2 \mathrm{~Sv}$ westernLDW (of which $1 \mathrm{~Sv}$ joining the Deep Western Boundary Current around $50^{\circ} \mathrm{N}$ and $1 \mathrm{~Sv}$ around $30^{\circ} \mathrm{N}$ ).

[24] 2. $6 \mathrm{~Sv}$ MiddleNADW composed of $2 \mathrm{~Sv}$ pISOW, 2 Sv of entrained Modified North Atlantic Water and LSW and 2 Sv easternLDW.

[25] 3. $4 \mathrm{~Sv}$ UpperNADW composed of LSW mixed with Mediterranean Outflow Water (MOW).

[26] As the above described water masses leave the studied area (off Flemish Cap, east of Newfoundland), the NADW is mostly but not entirely formed. Piepgras and Wasserburg [1987] named it "proto-NADW." Its three layers are then composed of NWABW (proto-LowerNADW), NEADW (proto-MiddleNADW) and LSW (proto-UpperNADW). Contributions of Mediterranean Outflow Water and western LDW complete the formation of NADW south of the studied area.

\section{Analytical Procedures}

[27] Seawater samples were analyzed for $\mathrm{Nd} \mathrm{IC}$ and REE concentrations following the procedures described by Lacan and Jeandel [2001], slightly modified as described by Lacan and Jeandel [2004c]. Samples were unfiltered in most cases, although a few (see Tables 2 and 3 ) were filtered, within a few hours of sampling, through $0.45 \mu \mathrm{m}$ nuclepore filters.

[28] Briefly, for the Nd IC analysis, the Nd was quantitatively extracted from a $10 \mathrm{~L}$ sample by three consecutive ion exchange chromatographies, the first of which was carried out onboard, which considerably reduced sample sizes and therefore allowed extensive sampling. Nd IC was then measured on a Finnigan MAT 261 Thermo Ionization Mass Spectrometer (TIMS) at the Observatoire Midi Pyrénées, Toulouse, France, in static mode; $\mathrm{Nd}$ was analyzed as $\mathrm{Nd}^{+}$. Internal precision was 0.2 to $0.3 \varepsilon_{\mathrm{Nd}}$ units $\left(2 \sigma_{\mathrm{n}}\right)$. The national Rennes $\mathrm{Nd}$ standard (recommended value ${ }^{143} \mathrm{Nd} /{ }^{144} \mathrm{Nd}=$ $0.511963 \pm 13(2 \sigma)$; C. Chauvel, personal communication 2002), calibrated against the La Jolla standard (recommended value ${ }^{143} \mathrm{Nd} /{ }^{144} \mathrm{Nd}=$ $0.511850 \pm 20(2 \sigma)$, G.W. Lugmair, personal communication, 2001) gave ${ }^{143} \mathrm{Nd} /{ }^{144} \mathrm{Nd}=$

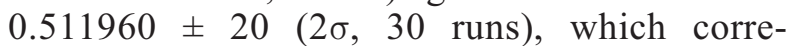
sponded to a La Jolla value of 0.511847 . No corrections were applied to measured isotopic ratios. The reproducibility of the Nd IC measurement was $0.4 \varepsilon_{\mathrm{Nd}}$ unit, blank values were $700 \mathrm{pg}$ (3.2\% of the most depleted sample and $2.4 \%$ on average).

[29] For the REE concentrations analysis, the REE were extracted from a $500 \mathrm{~mL}$ sample, by iron oxide coprecipitation. REE were then separated from iron by ion exchange chromatography. REE concentrations were measured with a Perkin-Elmer Elan 6000 Inductively Coupled Plasma Mass Spectrometer (ICPMS, in the same laboratory). $\mathrm{Nd}$ and $\mathrm{Yb}$ concentrations were measured by isotopic dilution. Reproducibility of the REE concentration measurements was better than 10\% for all REE and better than $5 \%$ for $\mathrm{Nd}$, blanks values were better than $8 \%$ for all REE and better than $3 \%$ for $\mathrm{Nd}$. Internal precision $\left(2 \sigma_{\mathrm{n}}\right)$ was better than $10 \%$ for all REE and lower than $0.2 \mathrm{ppt}$ (part per trillion, $1 \mathrm{ppt}$ $=10^{-12} \mathrm{~g} \mathrm{~g}^{-1}$ ) for $\mathrm{Nd}$. For several samples, Nd concentration only (not those of all REE) was measured.

\section{Results and Discussion}

[30] Measured Nd IC and concentrations, together with hydrographical parameters are reported in Table 2. Figure 4 displays the $\varepsilon_{\mathrm{Nd}}$ values along three surface maps corresponding to the three NADW layers.

[31] The section consisting of stations 14, 15, and 16 (Figure 1), located just downstream of Denmark Strait, is characterized by a very complex hydrography, due to the rapid sinking of the overflow waters. For this reason, hydrographical parameters (reported in Table 2, but not displayed in Figure 3 
Table 2. Seawater Sample Hydrographical Parameters and Nd Isotopic Compositions and Concentrations ${ }^{\mathrm{a}}$

\begin{tabular}{|c|c|c|c|c|c|c|c|}
\hline $\begin{array}{l}\text { Station (Number, } \\
\text { Location, } \\
\text { Date, Depth) }\end{array}$ & $\begin{array}{l}\text { Depth, } \\
\text { m }\end{array}$ & $\theta,{ }^{\circ} \mathrm{C}$ & Salinity & $\begin{array}{l}\text { Potential } \\
\text { Density, } \\
\mathrm{kg} \mathrm{m}^{-3}\end{array}$ & $\begin{array}{l}{\left[\mathrm{O}_{2}\right],} \\
\mathrm{mg} \mathrm{L}^{-1}\end{array}$ & $\varepsilon_{\mathrm{Nd}}$ & $10^{-12} \mathrm{~g} \mathrm{~g}^{-1}$ \\
\hline $\begin{array}{l}\text { Station } 1, \\
52.08^{\circ} \mathrm{W}, 55.02^{\circ} \mathrm{N} \\
05 / 07 / 99,2716 \mathrm{~m}\end{array}$ & $\begin{array}{c}21 \\
198\end{array}$ & $\begin{array}{l}4.81 \\
3.80\end{array}$ & $\begin{array}{l}34.43 \\
34.79\end{array}$ & $\begin{array}{l}27.25 \\
27.64\end{array}$ & $\begin{array}{c}10.62 \\
9.42\end{array}$ & $\begin{array}{l}-15.5 \\
-14.6^{b}\end{array}$ & $\begin{array}{c}2.5 \\
-\end{array}$ \\
\hline $\begin{array}{l}\text { Station } 2, \\
47.07^{\circ} \mathrm{W}, 58.55^{\circ} \mathrm{N} \\
06 / 07 / 99,2901 \mathrm{~m}\end{array}$ & $\begin{array}{c}30 \\
101 \\
230 \\
600 \\
1000 \\
\mathbf{1 6 0 0}^{\mathrm{c}} \\
\mathbf{2 2 7 0}^{\mathrm{d}} \\
2550 \\
2796^{\mathrm{e}}\end{array}$ & $\begin{array}{l}5.12 \\
4.19 \\
4.27 \\
3.52 \\
3.27 \\
2.87 \\
2.57 \\
2.10 \\
1.29\end{array}$ & $\begin{array}{l}34.49 \\
34.78 \\
34.90 \\
34.84 \\
34.86 \\
34.85 \\
34.89 \\
34.89 \\
34.84\end{array}$ & $\begin{array}{l}27.25 \\
27.59 \\
27.67 \\
27.71 \\
27.75 \\
27.77 \\
27.84 \\
27.87 \\
27.90\end{array}$ & $\begin{array}{l}10.00 \\
9.72 \\
9.38 \\
9.43 \\
9.14 \\
9.47 \\
9.16 \\
9.26 \\
9.82\end{array}$ & $\begin{array}{l}-13.6 \\
-14.0 \\
-14.3 \\
-13.9 \\
-13.6 \\
-13.5 \\
-12.6 \\
-12.1 \\
-10.5\end{array}$ & $\begin{array}{l}2.7^{\mathrm{b}} \\
2.8 \\
- \\
2.7 \\
2.7 \\
2.5 \\
2.5 \\
2.6 \\
3.0^{\mathrm{f}}\end{array}$ \\
\hline $\begin{array}{l}\text { Station } 3, \\
62.65^{\circ} \mathrm{N}, 53.90^{\circ} \mathrm{W} \\
09 / 07 / 99,2476 \mathrm{~m}\end{array}$ & $\begin{array}{c}16 \\
41 \\
178 \\
400 \\
998 \\
1700^{\mathrm{c}} \\
2251^{\mathrm{d}} \\
2431^{\mathrm{e}}\end{array}$ & $\begin{array}{l}3.85 \\
2.83 \\
4.70 \\
4.36 \\
3.42 \\
2.87 \\
2.50 \\
1.83\end{array}$ & $\begin{array}{l}33.61 \\
33.96 \\
34.87 \\
34.90 \\
34.86 \\
34.86 \\
34.88 \\
34.87\end{array}$ & $\begin{array}{l}26.70 \\
27.07 \\
27.61 \\
27.67 \\
27.74 \\
27.78 \\
27.84 \\
27.88\end{array}$ & $\begin{array}{c}10.87 \\
10.50 \\
9.14 \\
9.14 \\
9.06 \\
9.33 \\
9.20 \\
9.45\end{array}$ & $\begin{array}{l}-15.1 \\
-14.3 \\
-15.1^{b} \\
-14.9 \\
-15.1 \\
-14.5 \\
-16.4 \\
-14.9\end{array}$ & $\begin{array}{c}3.4 \\
- \\
- \\
4.0 \\
3.1^{\mathrm{b}} \\
3.7 \\
- \\
-\end{array}$ \\
\hline $\begin{array}{l}\text { Station } 4 \text {, } \\
57.96^{\circ} \mathrm{N}, 57.39^{\circ} \mathrm{W}, \\
11 / 07 / 99 \text {, depth unknown }\end{array}$ & $\begin{array}{l}\sim 7 \\
\sim 7\end{array}$ & $\begin{array}{l}\sim 6 \\
\sim 6\end{array}$ & $\begin{array}{l}\sim 34 \\
\sim 34\end{array}$ & - & - & $\begin{array}{l}-15.8^{b} \\
-15.8\end{array}$ & $\begin{array}{l}3.9^{\mathrm{b}} \\
3.9\end{array}$ \\
\hline $\begin{array}{l}\text { Station } 5 \text {, } \\
55,01^{\circ} \mathrm{N}, 56.40^{\circ} \mathrm{W}, \\
11 / 07 / 99 \text {, depth unknown }\end{array}$ & $\sim 7$ & $\sim 1.5$ & $\sim 30.6$ & - & - & $-24.9^{\mathrm{b}}$ & $6.3^{\mathrm{b}}$ \\
\hline $\begin{array}{l}\text { Station } 6 \\
50.20^{\circ} \mathrm{N}, 45.68^{\circ} \mathrm{W} \\
14 / 07 / 99,3540 \mathrm{~m}\end{array}$ & $\begin{array}{l}26 \\
1650^{\mathrm{c}} \\
2499^{\mathrm{d}} \\
3501^{\mathrm{e}}\end{array}$ & $\begin{array}{l}8.65 \\
2.99 \\
2.70 \\
1.79\end{array}$ & $\begin{array}{l}33.92 \\
34.86 \\
34.90 \\
34.88\end{array}$ & $\begin{array}{l}26.33 \\
27.77 \\
27.84 \\
27.89\end{array}$ & $\begin{array}{l}9.75 \\
9.29 \\
9.06 \\
9.45\end{array}$ & $\begin{array}{l}-20.2 \\
-13.9 \\
-13.2 \\
-14.5\end{array}$ & $\begin{array}{c}4.9 \\
2.5 \\
2.6 \\
-\end{array}$ \\
\hline $\begin{array}{l}\text { Station } 7 \\
55.55^{\circ} \mathrm{N}, 43.97^{\circ} \mathrm{W} \\
16 / 07 / 99,3225 \mathrm{~m}\end{array}$ & $\begin{array}{c}40 \\
325 \\
476 \\
\mathbf{9 2 6}^{2} \\
\mathbf{2 1 0 1}^{\mathrm{d}} \\
\mathbf{2 7 5 0}^{\mathrm{d}} \\
\mathbf{3 2 7 0}^{\mathrm{e}}\end{array}$ & $\begin{array}{l}6.60 \\
3.43 \\
3.42 \\
3.21 \\
2.91 \\
2.62 \\
2.12\end{array}$ & $\begin{array}{l}34.63 \\
34.82 \\
34.84 \\
34.86 \\
34.89 \\
34.92 \\
34.90\end{array}$ & $\begin{array}{l}27.19 \\
27.70 \\
27.72 \\
27.75 \\
27.80 \\
27.86 \\
27.88\end{array}$ & $\begin{array}{l}9.89 \\
9.28 \\
9.14 \\
9.07 \\
9.15 \\
8.96 \\
9.18\end{array}$ & $\begin{array}{l}-15.6 \\
-14.7 \\
-14.6 \\
-14.1 \\
-13.3 \\
-12.8 \\
-12.9\end{array}$ & $\begin{array}{l}3.1 \\
2.7 \\
2.9 \\
2.6 \\
3.0 \\
2.7 \\
3.3\end{array}$ \\
\hline $\begin{array}{l}\text { Station } 8, \\
62.07^{\circ} \mathrm{N}, 40.19^{\circ} \mathrm{W} \\
16 / 07 / 99,3225 \mathrm{~m}\end{array}$ & 201 & 5.90 & 35.02 & 27.59 & 8.84 & -14.2 & 3.0 \\
\hline $\begin{array}{l}\text { Station } 9 \\
62.70^{\circ} \mathrm{N}, 37.59^{\circ} \mathrm{W} \\
18 / 07 / 99,2125 \mathrm{~m}\end{array}$ & $\begin{array}{l}25 \\
101 \\
205 \\
601\end{array}$ & $\begin{array}{l}9.33 \\
6.48 \\
5.60 \\
4.10\end{array}$ & $\begin{array}{l}35.01 \\
35.05 \\
35.00 \\
34.90\end{array}$ & $\begin{array}{l}27.07 \\
27.53 \\
27.60 \\
27.70\end{array}$ & $\begin{array}{l}9.68 \\
8.79 \\
8.88 \\
9.04\end{array}$ & $\begin{array}{l}-14.6 \\
-13.9 \\
-14.1 \\
-13.3\end{array}$ & $\begin{array}{l}2.7 \\
2.7 \\
2.8 \\
2.7\end{array}$ \\
\hline
\end{tabular}


Table 2. (continued)

\begin{tabular}{|c|c|c|c|c|c|c|c|}
\hline $\begin{array}{c}\text { Station (Number, } \\
\text { Location, } \\
\text { Date, Depth) }\end{array}$ & $\begin{array}{l}\text { Depth, } \\
\text { m }\end{array}$ & $\theta,{ }^{\circ} \mathrm{C}$ & Salinity & $\begin{array}{l}\text { Potential } \\
\text { Density, } \\
\mathrm{kg} \mathrm{m}^{-3}\end{array}$ & $\begin{array}{l}{\left[\mathrm{O}_{2}\right]} \\
\mathrm{mg} \mathrm{L}^{-1}\end{array}$ & $\varepsilon_{\mathrm{Nd}}$ & $10^{-12} \mathrm{~g} \mathrm{~g}^{-1}$ \\
\hline & $\begin{array}{c}1026 \\
1519^{\mathrm{c}} \\
1801 \\
2100^{\mathrm{e}}\end{array}$ & $\begin{array}{l}3.41 \\
2.88 \\
2.70 \\
1.22\end{array}$ & $\begin{array}{l}34.89 \\
34.85 \\
34.87 \\
34.85\end{array}$ & $\begin{array}{l}27.76 \\
27.78 \\
27.81 \\
27.91\end{array}$ & $\begin{array}{l}8.99 \\
9.47 \\
9.39 \\
9.99\end{array}$ & $\begin{array}{l}-13.8 \\
-13.2 \\
-12.3 \\
-9.5\end{array}$ & $\begin{array}{l}2.8 \\
2.8 \\
2.9 \\
3.4\end{array}$ \\
\hline $\begin{array}{l}\text { Station } 12, \\
56.37^{\circ} \mathrm{N}, 27.82^{\circ} \mathrm{W}, \\
22 / 07 / 99,2840 \mathrm{~m}\end{array}$ & $\begin{array}{c}20 \\
74 \\
250 \\
351 \\
500 \\
651 \\
1101 \\
\mathbf{1 7 5 0}^{\text {c }} \\
\mathbf{2 5 0 0}^{\text {d }} \\
\mathbf{2 8 2 8}^{\text {d }}\end{array}$ & $\begin{array}{c}11.39 \\
9.97 \\
6.90 \\
6.37 \\
5.47 \\
4.91 \\
3.65 \\
3.07 \\
2.66 \\
2.48\end{array}$ & $\begin{array}{l}35.00 \\
35.07 \\
34.89 \\
34.91 \\
34.94 \\
34.97 \\
34.90 \\
34.88 \\
34.95 \\
34.96\end{array}$ & $\begin{array}{l}26.70 \\
27.01 \\
27.35 \\
27.43 \\
27.57 \\
27.66 \\
27.74 \\
27.78 \\
27.88 \\
27.90\end{array}$ & $\begin{array}{l}8.52 \\
8.53 \\
7.68 \\
7.86 \\
7.41 \\
7.69 \\
8.68 \\
9.21 \\
8.85 \\
8.99\end{array}$ & $\begin{array}{l}-14.8 \\
-14.9 \\
-15.1 \\
-15.0 \\
-14.8 \\
-14.7 \\
-14.3 \\
-14.1 \\
-12.6 \\
-10.1\end{array}$ & $\begin{array}{l}2.5 \\
2.8 \\
2.8 \\
2.9 \\
2.8 \\
2.8 \\
2.6 \\
2.7 \\
2.9 \\
2.7\end{array}$ \\
\hline $\begin{array}{l}\text { Station } 14, \\
65.02^{\circ} \mathrm{N}, 30.23^{\circ} \mathrm{W} \text {, } \\
27 / 07 / 99,1875 \mathrm{~m}\end{array}$ & $\begin{array}{c}31 \\
401 \\
549 \\
\mathbf{1 2 2 9} \\
\mathbf{1 8 6 0}\end{array}$ & $\begin{array}{l}9.55 \\
6.46 \\
5.63 \\
3.70 \\
2.35\end{array}$ & $\begin{array}{l}35.06 \\
35.09 \\
35.02 \\
34.93 \\
34.89\end{array}$ & $\begin{array}{l}27.08 \\
27.56 \\
27.61 \\
27.77 \\
27.85\end{array}$ & $\begin{array}{l}9.14 \\
8.68 \\
8.53 \\
8.85 \\
9.47\end{array}$ & $\begin{array}{l}-14.0 \\
-13.2 \\
-13.6 \\
-12.8 \\
-11.2\end{array}$ & $\begin{array}{l}2.2 \\
2.6 \\
2.6 \\
2.7 \\
2.7\end{array}$ \\
\hline $\begin{array}{l}\text { Station } 15, \\
65.32^{\circ} \mathrm{N}, 30.88^{\circ} \mathrm{W} \text {, } \\
27 / 07 / 99,993 \mathrm{~m}\end{array}$ & $\begin{array}{c}20 \\
750 \\
800 \\
\mathbf{9 8 4}\end{array}$ & $\begin{array}{l}8.87 \\
4.49 \\
4.44 \\
1.36\end{array}$ & $\begin{array}{l}35.09 \\
34.94 \\
34.96 \\
34.82\end{array}$ & $\begin{array}{l}27.21 \\
27.68 \\
27.71 \\
27.88\end{array}$ & $\begin{array}{c}9.28 \\
8.77 \\
8.48 \\
10.08\end{array}$ & $\begin{array}{l}-13.7 \\
-13.7 \\
-13.1 \\
-10.6\end{array}$ & $\begin{array}{l}2.4 \\
2.5 \\
2.6 \\
2.7\end{array}$ \\
\hline $\begin{array}{l}\text { Station } 16, \\
65.17^{\circ} \mathrm{N}, 30.52^{\circ} \mathrm{W} \text {, } \\
27 / 07 / 99,1500 \mathrm{~m}\end{array}$ & $\begin{array}{c}200 \\
1002 \\
1299 \\
1399\end{array}$ & $\begin{array}{l}7.05 \\
3.82 \\
0.92 \\
0.49\end{array}$ & $\begin{array}{l}35.14 \\
34.94 \\
34.77 \\
34.81\end{array}$ & $\begin{array}{l}27.52 \\
27.76 \\
27.86 \\
27.93\end{array}$ & $\begin{array}{c}9.13 \\
8.76 \\
10.40 \\
10.50\end{array}$ & $\begin{array}{l}-14.2 \\
-11.8 \\
-10.7 \\
-10.4\end{array}$ & $\begin{array}{c}2.9 \\
- \\
3.0 \\
2.9\end{array}$ \\
\hline
\end{tabular}

for reasons of clarity) do not allow identification of the different proto-NADW layers (LSW, NEADW and NWABW). Therefore these stations are not included in Figure 4. Neither are stations 1, 4, 5 and 8 , at which surface samples only have been analyzed.

[32] REE concentrations are reported in Table 3. REE patterns are much weaker than $\varepsilon_{\mathrm{Nd}}$ as tracers of water mass mixing or for reconstruction of paleocirculation and weathering regimes. On the other hand, REE properties allow the identification of recent lithogenic inputs. Therefore they will only be used here to support Nd IC data in that regard.

\subsection{NWABW}

[33] According to Schmitz [1996], downstream of the Denmark Strait, the sinking of $\sim 3$ Sv DSOW entrains $\sim 3 \mathrm{~Sv}$ of LSW and SPMW toward the depths of the Irminger basin, thus forming the NWABW. McCartney [1992] suggests that these entrainments occur along the eastern Greenland margin, between the Denmark Strait and Cape Farewell (southernmost point of Greenland). The DSOW Nd IC is $\approx-8.4$ [Piepgras and Wasserburg, 1987; Lacan and Jeandel, 2004a]. Along the eastern Greenland margin, the NWABW signature decreases. It is -9.5 at station 9 and -10.5 at the southern tip of Greenland (station 2; 


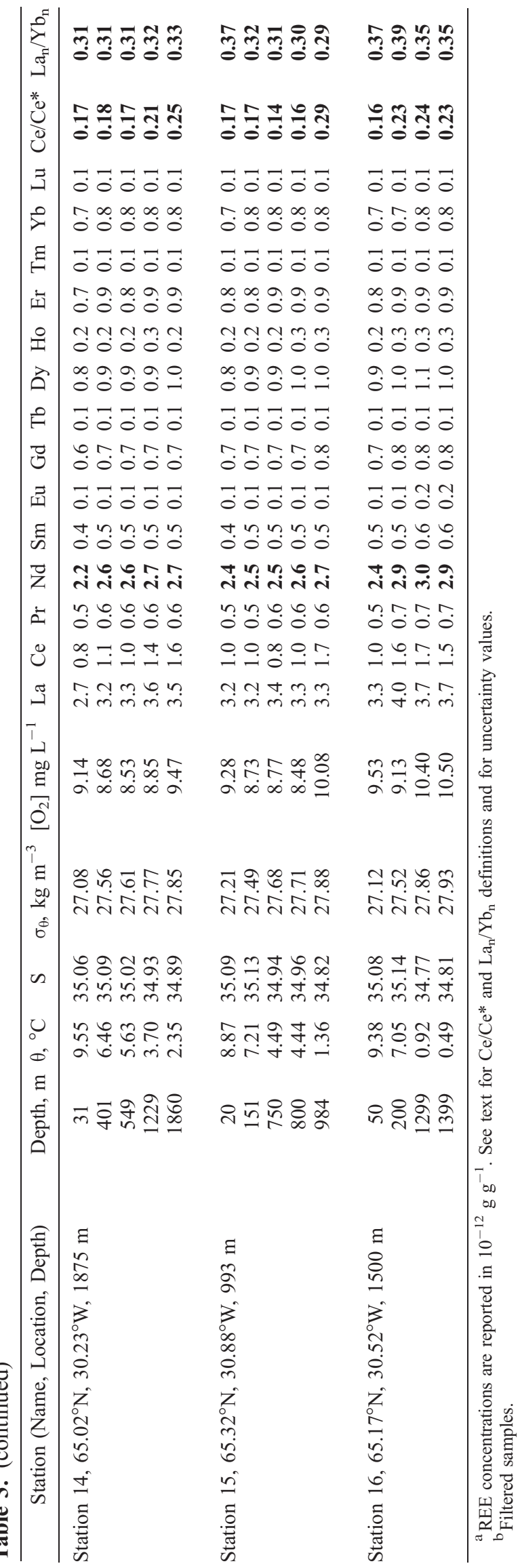



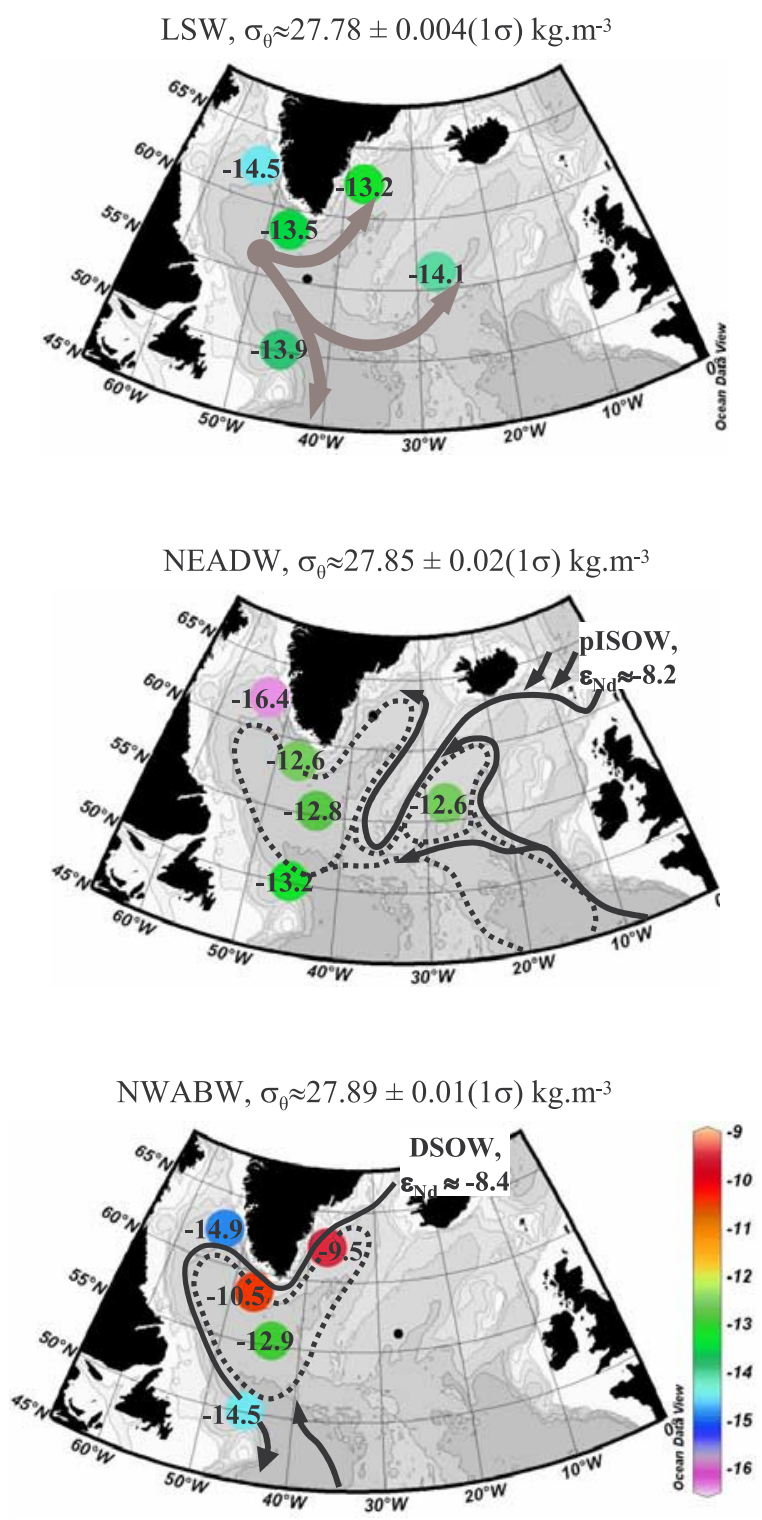

Figure 4. Distribution of $\varepsilon_{\mathrm{Nd}}$ along isopycnal surfaces characterizing the core of the three proto-NADW layers (the data used are identified in Table 2 by c, d, and e superscripts). For each panel, the potential density reported is the average of those of the samples for which Nd IC are displayed. Maps created with the Ocean Data View Software (R. Schlitzler, Ocean Data View, 2004; available at http://www.awi-bremerhaven.de/GEO/ ODV).

see Figure 4). In the following section, an attempt to understand this overall decrease from -8.4 in the Denmark Strait to -10.5 at station 2 will be made.

[34] In order to verify if the NWABW Nd IC at station 2 (Figure 1) can be explained the mixing proposed by Schmitz [1996], the calculation of the
$\mathrm{Nd}$ IC of the water mass resulting from this mixing is performed using the $\mathrm{Nd} \mathrm{IC}$ and concentration of the different end-members (DSOW, LSW and SPMW); the resulting $\mathrm{Nd}$ IC is the average of those of the end-members weighted by their $\mathrm{Nd}$ concentrations and the mixing proportions. This calculation is also performed for the usual conservative tracers (salinity, potential temperature and dissolved oxygen).

[35] The DSOW characteristics, averaged from 4 samples taken in the Denmark Strait, are reported in Table $4\left(\varepsilon_{\mathrm{Nd}}=-8.4 \pm 1.2,[\mathrm{Nd}]=3.2 \pm 0.5 \mathrm{ppt}\right.$, $\mathrm{S}=34.88 \pm 0.0, \theta=-0.2 \pm 0.2^{\circ} \mathrm{C},\left[\mathrm{O}_{2}\right]=10.16 \pm$ $0.1 \mathrm{mg} \mathrm{L}^{-1}$ ). The LSW characteristics are determined from the sample taken in the salinity minimum (and oxygen maximum) at station $2(1600 \mathrm{~m}$; see Figure 3 and Table $2: \varepsilon_{\mathrm{Nd}}=-13.5 \pm 0.4,[\mathrm{Nd}]=$ $2.5 \pm 0.2 \mathrm{ppt}, \mathrm{S}=34.85, \theta=2.87^{\circ} \mathrm{C},\left[\mathrm{O}_{2}\right]=$ $9.47 \mathrm{mg} \mathrm{L}^{-1}$ ), which displays the most pronounced extrema among our data set and therefore represents the purest form of LSW sampled. The SPMW end-member is more complex to define, since its properties vary around the North Atlantic Subpolar Gyre. According to the above descriptions, the SPMW is supposed to be entrained along the eastern Greenland margin. Therefore stations $14-15-16$ or station 9 could, in principle, provide the appropriate SPMW characteristics. However, DSOW and LSW are saltier than the resulting NWABW $(\mathrm{S}=34.88,34.85$ and 34.84 , respectively), implying that the other component should be fresher. SPMW found at stations 14$15-16$ and 9 are too saline ( $\approx 35.0$; see Table 2$)$ to account for the relatively low NWABW salinity. On the other hand, the SPMW found at station 2 is fresher, making this water mass a good candidate for the mixing. Its characteristics, averaged from 5 samples with $\sigma_{\theta}<27.75 \mathrm{~kg} \mathrm{~m}^{-3}$ (this density level corresponding to the lower SPMW boundary [Lacan and Jeandel, 2004c]) will thus be used to define the SPMW end-member (see Table 4: $\varepsilon_{\mathrm{Nd}}=$ $-13.9 \pm 0.2,[\mathrm{Nd}]=2.7 \pm 0.1 \mathrm{ppt}, \mathrm{S}=34.77 \pm 0.1$, $\theta=4.07 \pm 0.5^{\circ} \mathrm{C},\left[\mathrm{O}_{2}\right]=9.53 \pm 0.3 \mathrm{mg} \mathrm{L}^{-1}$ ).

[36] The mixing described by Schmitz [1996] involves $1 / 2$ DSOW and $1 / 2$ (LSW + SPMW). Assuming equal contributions of LSW and SPMW $(1 / 4$ each $)$, the calculated characteristics of the resulting water mass are $\varepsilon_{\mathrm{Nd}}=-10.8 \pm 0.7, \mathrm{~S}=$ $34.85 \pm 0.03, \theta=1.63 \pm 0.2^{\circ} \mathrm{C},\left[\mathrm{O}_{2}\right]=9.83 \pm$ $0.1 \mathrm{mg} \mathrm{L}^{-1}$. These values are very consistent with the NWABW characteristics measured at station 2 $\left(\varepsilon_{\mathrm{Nd}}=-10.5 \pm 0.4, \mathrm{~S}=34.84, \theta=1.29^{\circ} \mathrm{C}\right.$ and $\left.\left[\mathrm{O}_{2}\right]=9.82 \mathrm{mg} \mathrm{L}^{-1}\right)$. Indeed, discrepancies be- 


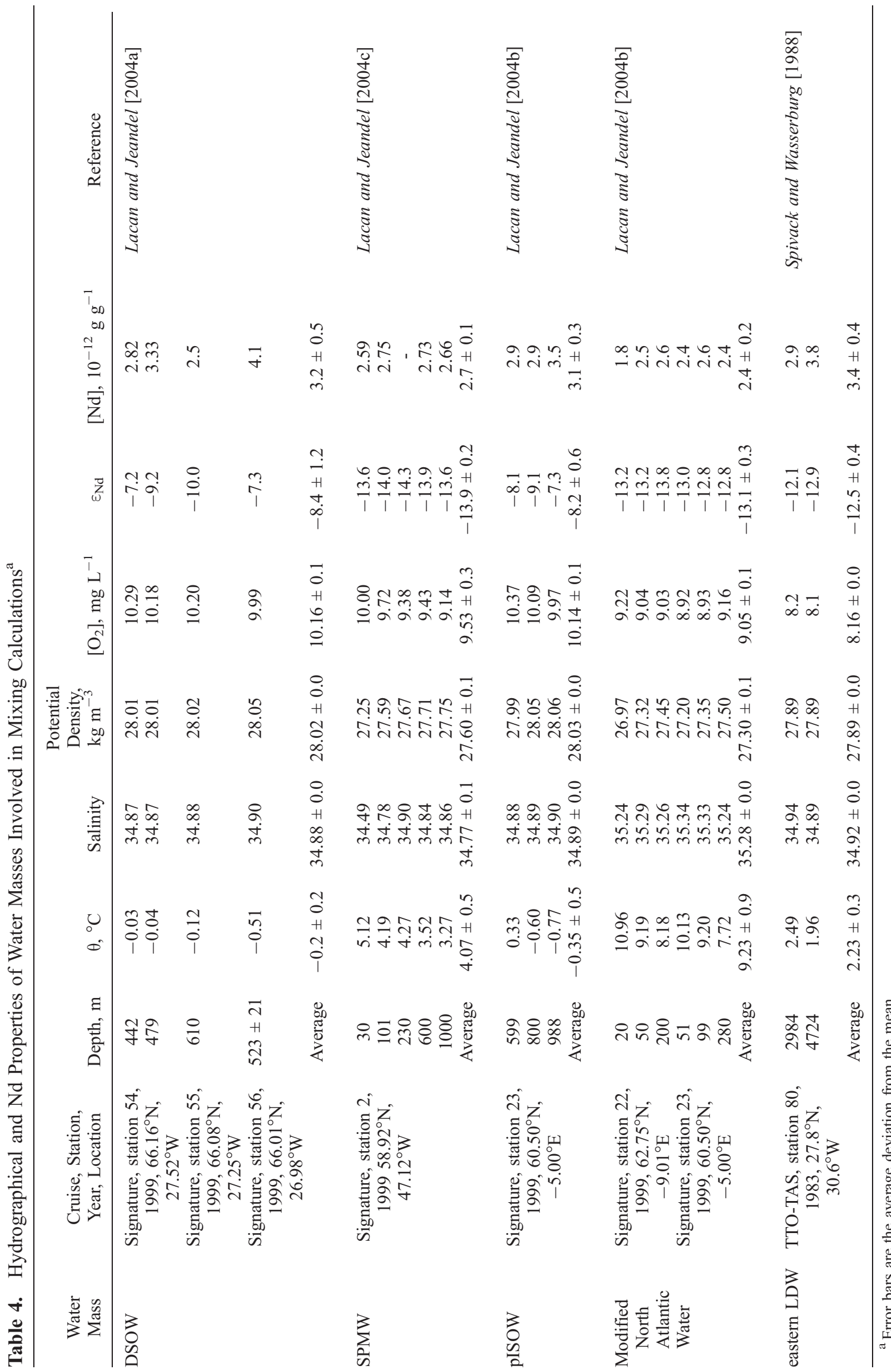


tween measured and calculated values are small compared to the variation ranges of each parameter between the end-members $(5 \% 6 \%, 8 \%$ and $2 \%$ for $\varepsilon_{\mathrm{Nd}}, \mathrm{S}, \theta$ and $\left[\mathrm{O}_{2}\right]$, respectively).

[37] These results confirm the mixing scenario proposed by Schmitz [1996], and explain the $\varepsilon_{\mathrm{Nd}}$ decrease from -8.4 in the DSOW to -10.5 in the NWABW at the Southern tip of Greenland. However, unlike what could be understood from the Schmitz [1996] and McCartney [1992] descriptions, hydrographical properties suggest that the SPMW contribution involves a significantly fresher SPMW variety than that found immediately downstream of Denmark Strait. The latter conclusion needs however to be qualified by the fact that temporal variabilities may significantly modify SPMW property distributions [Talley, 1999].

[38] Further downstream, between stations 2 and 3 (Figure 1), the NWABW Nd IC decreases very significantly from $\varepsilon_{\mathrm{Nd}}=-10.5$ to -14.9 . This decrease is associated with salinity and temperature increases and a decrease in oxygen concentration (see Table 2; NWABW properties at station 2: $\varepsilon_{\mathrm{Nd}}=-10.5 \pm 0.4,[\mathrm{Nd}]=3.0 \pm 0.2 \mathrm{ppt}$, $\mathrm{S}=34.84, \theta=1.29^{\circ} \mathrm{C},\left[\mathrm{O}_{2}\right]=9.82 \mathrm{mg} \mathrm{L}^{-1}$; and at station $3: \varepsilon_{\mathrm{Nd}}=-14.9 \pm 0.4, \mathrm{~S}=34.87, \theta=$ $1.83^{\circ} \mathrm{C},\left[\mathrm{O}_{2}\right]=9.45 \mathrm{mg} \mathrm{L}^{-1}$ ). These hydrographical variations probably reflect a mixing of NWABW with the overlying NEADW, characterized at station 2, $2550 \mathrm{~m}$ depth, by $\varepsilon_{\mathrm{Nd}}=-12.1 \pm$ $0.4,[\mathrm{Nd}]=2.6 \pm 0.2 \mathrm{ppt}, \mathrm{S}=34.885, \theta=2.10^{\circ} \mathrm{C}$ and $\left[\mathrm{O}_{2}\right]=9.26 \mathrm{mg} \mathrm{L}^{-1}$ (two NEADW samples were analyzed at station 2: the purest NEADW form was sampled at $2270 \mathrm{~m}$ depth, whereas the sample used here represents the NEADW layer just above the NWABW). According to this hypothesis, conservation of salinity, potential temperature and dissolved oxygen concentration imply mixing proportions of $67 \%, 67 \%$ and $66 \%$ NEADW, respectively. The consistency of these results strongly confirms the mixing hypothesis. However, given that this mixing yields a NWABW Nd IC of -11.5 , this process alone is unable to explain the very negative NWABW Nd IC of -14.9. Therefore, out of the $4.4 \varepsilon_{\mathrm{Nd}}$ unit decrease of the NWABW between stations 2 and $3,3.4 \varepsilon_{\mathrm{Nd}}$ units cannot be explained by water mass mixing and therefore must result from external inputs. Unfortunately, no sample was collected for REE concentration measurements in the NWABW at station 3. However, all the samples analyzed for REE concentrations at this station (400, 998 and $1700 \mathrm{~m}$ depth; see Table 3) display high $\mathrm{Nd}$ concentrations and high values of $\mathrm{Ce} / \mathrm{Ce} e^{*}$ and $\mathrm{La}_{\mathrm{n}} / \mathrm{Yb}_{\mathrm{n}}$ (values of the order of 3.6 ppt, 0.4 and 0.5 , for [Nd], Ce/Ce* and $\mathrm{La}_{\mathrm{n}} / \mathrm{Yb}_{\mathrm{n}}$, respectively; whereas typical oceanic values in this area are $2.6 \mathrm{ppt}, 0.2$ and 0.3 , for $[\mathrm{Nd}], \mathrm{Ce} /$ Ce* and $\mathrm{La}_{\mathrm{n}} / \mathrm{Yb}_{\mathrm{n}}$, respectively), indicating the occurrence of recent lithogenic inputs and suggesting that they could affect the whole water column.

[39] The NWABW found at station 6 (Figure 1), located further downstream of station 3, displays similar hydrographical and $\mathrm{Nd}$ characteristics $\left(\varepsilon_{\mathrm{Nd}}=-14.5\right)$ as those found at station 3. This suggests that these lithogenic enrichments affect the bulk of the NWABW, which represents a flux of approximately $6 \mathrm{~Sv}$ in the studied area (the $2 \mathrm{~Sv}$ of western LDW not merging with the NWABW north of $50^{\circ} \mathrm{N}$, according to Schmitz [1996]).

[40] The lithogenic inputs could come from dissolved river inputs, dust deposits or sediment remobilization. The southwest Greenland coast, of Archaean origin, is characterized by very negative Nd IC. Its dissolved and particulate river loads have been measured between $\varepsilon_{\mathrm{Nd}} \approx-43$ and -24 [Goldstein and Jacobsen, 1987; von Blanckenburg and Nägler, 2001]. The lower limit of this range is amongst the most negative Nd IC outcropping on earth. It can therefore be considered as a lower limit for particulate and dissolved river loads and aerosols. On the other hand, surface seafloor sediments, in contact with the NWABW in the vicinity of station 3 , are characterized by $\varepsilon_{\mathrm{Nd}} \approx$ -24 [Innocent et al., 1997]. We infer that, after the mixing lowers its $\varepsilon_{\mathrm{Nd}}$ to -11.5 (and yields an $\mathrm{Nd}$ concentration of $2.7 \mathrm{ppt}$ ), the NWABW receives the lithogenic inputs. This water mass totals $6 \mathrm{~Sv}$. The external input flux of $\mathrm{Nd}$ required to drop the NWABW Nd IC down to -14.9 at station 3 is estimated using equation (2):

$$
\varepsilon_{i} \times N d_{i} \times F_{w}+\varepsilon_{a} \times F_{a}=\varepsilon_{f} \times\left(N d_{i} \times F_{w}+F_{a}\right),
$$

where $\varepsilon_{\mathrm{i}}, \varepsilon_{\mathrm{f}}$ and $\varepsilon_{\mathrm{a}}$ stand for $\varepsilon_{\mathrm{Nd}}$ of the water mass before (initial) and after (final) the external input and for that of the added material (addition), respectively. $\mathrm{Nd}_{\mathrm{i}}$ is the initial $\mathrm{Nd}$ concentration, $\mathrm{F}_{\mathrm{w}}$ the water mass flux and $\mathrm{F}_{\mathrm{a}}$ the external flux of Nd. Here: $\varepsilon_{\mathrm{i}}=-11.5, \varepsilon_{\mathrm{f}}=$ $-14.9,-43<\varepsilon_{\mathrm{a}}<-24, \mathrm{Nd}_{\mathrm{i}}=2.7 \mathrm{ppt}, \mathrm{F}_{\mathrm{w}}=$ $6 \mathrm{~Sv} . \mathrm{F}_{\mathrm{a}}$ is calculated to be at least $2.0 \mathrm{~g} \mathrm{~s}^{-1}$ in the case of dissolved river loads and dust $\left(\varepsilon_{\mathrm{a}} \geq\right.$ 
-43) and $\sim 6.0 \mathrm{~g} \mathrm{~s}^{-1}$ in the case of sediment remobilization $\left(\varepsilon_{\mathrm{a}} \approx-24\right)$.

[41] The dissolved Nd concentration in rivers from South West Greenland is on average $330 \mathrm{ppt}$ [Goldstein and Jacobsen, 1987]. Assuming a freshwater flux of $1.6 \times 10^{3} \mathrm{~m}^{3} \mathrm{~s}^{-1}$ [Khatiwala et al., 1999], this leads to a flux of $0.5 \mathrm{~g} \mathrm{~s}^{-1}$. Considering that $70 \%$ of this flux is retained in estuaries [Goldstein and Jacobsen, 1987], the flux reaching the ocean would be $0.16 \mathrm{~g} \mathrm{~s}^{-1}$, which accounts for only $8 \%$ of the required $2.0 \mathrm{~g} \mathrm{~s}^{-1}$.

[42] Mineral aerosol fluxes to the ocean have been estimated to be lower than $1000 \mathrm{mg} \mathrm{m}^{-2} \mathrm{yr}^{-1}$ in the north of the North Atlantic [Duce et al., 1991]. The area located between stations 2 and 3 is approximately $600 \mathrm{~km}$ long and the Deep Western Boundary Current is thought to be approximately $150 \mathrm{~km}$ wide [Rhein, 2000]. Using an aerosol $\mathrm{Nd}$ concentration of $20 \times 10^{-6} \mathrm{~g} \mathrm{~g} \mathrm{~g}^{-1}$ and a dissolution ratio of $30 \%$ (dissolution ratios have been estimated between 2 and 30\% [Tachikawa et al., 2003]; the upper limit of this range has been chosen here in order to calculate an upper limit for the aeolian flux), the aerosol $\mathrm{Nd}$ flux is estimated to be lower than $0.02 \mathrm{~g} \mathrm{~s}^{-1}$, which accounts for only $1 \%$ of the required $2.0 \mathrm{~g} \mathrm{~s}^{-1}$.

[43] Sediment accumulation rates in this area are around $40 \mathrm{~cm} \mathrm{kyr}^{-1}$ [Innocent et al., 1997]. Considering that the NWABW interacts with the sediments over the area described above $(600 \mathrm{~km} \times 150 \mathrm{~km})$, that the sediment density is $\sim 1.5 \mathrm{~g} \mathrm{~cm}^{-3}$ [Carter and Raymo, 1999], and that their $\mathrm{Nd}$ concentration is $\sim 30 \times 10^{-6} \mathrm{~g} \mathrm{~g}^{-1}$ [Innocent et al., 1997], then the sediment accumulation corresponds to an $\mathrm{Nd}$ flux of $\sim 51 \mathrm{~g} \mathrm{~s}^{-1}$. Therefore the remobilization of $\sim 10 \%$ of the sediment flux reaching the seafloor (i.e., the sum of sediment accumulation and remobilization fluxes) would be sufficient to account for the external Nd flux required to explain the NWABW Nd IC $\left(6.0 \mathrm{~g} \mathrm{~s}^{-1}\right)$.

[44] Although the above quantifications need to be considered cautiously owing to the numerous assumptions and uncertainties about the Nd fluxes, they strongly suggest that the remobilization of sediments deposited at the bottom of the margin is the external source leading to the NWABW Nd IC decrease. Indeed, it is the only source large enough to account for the observed variations, the others being one or more orders of magnitude too low. Furthermore, the direct impact of dissolved river and aerosol fluxes would preferentially affect sur- face waters, whereas the NWABW flows around $2500 \mathrm{~m}$ depth. On the other hand, sediment remobilization, enhanced by dynamic flows such as the Deep Western Boundary Current, may directly influence the Nd IC of water masses along continental margins. Such interactions have been reported previously along several margins [Lacan and Jeandel, 2005, and references therein]. This conclusion significantly contrasts with Piepgras and Wasserburg's [1987] hypothesis according to which the negative $\mathrm{Nd}$ signature of the bottom and deep Labrador Sea Water masses could result from deep convection of unradiogenic surface waters originating from the Labrador Current and Baffin Bay.

[45] In the absence of other fluxes, the sediment remobilization described above $\left(6.0 \mathrm{~g}(\mathrm{Nd}) \mathrm{s}^{-1}\right)$ should increase the NWABW Nd concentration from $2.7 \mathrm{ppt}$ to $3.7 \mathrm{ppt}$. The NWABW Nd concentration could not be measured at station 3. However, previously published data off Flemish Cap and further south within the Deep Western Boundary Current, suggest that it is $\sim 2.8$ ppt [Piepgras and Wasserburg, 1987]. This value is not significantly different from that characterizing the water mass before the Nd input. Therefore, as discussed by Lacan and Jeandel [2005], sediment remobilization leading to the Nd IC variation is probably associated with $\mathrm{Nd}$ removal fluxes $(\mathrm{Nd}$ removal fluxes having in principle no influence on the water mass $\mathrm{Nd} \mathrm{IC)} \mathrm{from} \mathrm{the} \mathrm{water} \mathrm{mass} \mathrm{toward} \mathrm{the}$ sediment, a process called boundary exchange. The occurrence of such fluxes is consistent with partial leaching experiments conducted on Baffin Bay sediments, which suggest that the more radiogenic Nd IC of their labile fraction is due to adsorption from seawater [von Blanckenburg and Nägler, 2001].

\subsection{NEADW}

[46] As shown in Figure 4, the NEADW Nd IC is very homogeneous within the studied area (with values ranging between -13.2 and -12.6 ), except at station 3 (Figure 1) where it is almost $4 \varepsilon_{\mathrm{Nd}}$ units less $\left(\varepsilon_{\mathrm{Nd}}=-16.4\right)$. Owing to our conclusions about the NWABW and the REE concentrations measured at this station, this negative value probably results from terrigeneous inputs. However, unlike the NWABW, the NEADW at station 6 hardly reflects this negative signature. This Nd IC difference between stations 3 and 6 , measured in samples having the same density $\left(\sigma_{\theta}=27.84 \mathrm{~kg} \mathrm{~m}^{-3}\right)$, suggests that the NEADW at station 6 does not 
directly come from station 3. On the other hand, the similarity of the NEADW Nd IC at all stations except station 3 suggests that this water mass is actively mixed between these stations. Therefore two hypotheses could explain the Nd IC difference between station 3 and 6: either the NEADW found at station 3 does not actively participate in the NEADW formation, or the NEADW mixing is so intense that the influence of station 3 is almost uniformly redistributed around the gyre, smoothing out any significant $\mathrm{Nd}$ IC horizontal gradient between the other stations.

[47] We initially assume that the NEADW signature at station 3 has a negligible impact on the rest of the gyre. The average NEADW Nd IC of the other stations is $\varepsilon_{\mathrm{Nd}}=-12.8 \pm 0.2$. According to Schmitz [1996], the NEADW is formed from about 1/3 pISOW, 1/3 easternLDW and 1/3 (Modified North Atlantic Water + LSW). Considering these mixing proportions and the $\mathrm{Nd}$ properties of the end-members defined in Table 4 (pISOW: $\varepsilon_{\mathrm{Nd}}=$ $-8.2 \pm 0.6,[\mathrm{Nd}]=3.1 \pm 0.3 \mathrm{ppt}$; easternLDW: $\varepsilon_{\mathrm{Nd}}=-12.5 \pm 0.4,[\mathrm{Nd}]=3.4 \pm 0.4 \mathrm{ppt}$; Modified North Atlantic Water: $\varepsilon_{\mathrm{Nd}}=-13.1 \pm 0.3,[\mathrm{Nd}]=$ $2.4 \pm 0.2 \mathrm{ppt}$; LSW properties defined as in the preceding section: $\varepsilon_{\mathrm{Nd}}=-13.5 \pm 0.4,[\mathrm{Nd}]=2.5 \pm$ $0.2 \mathrm{ppt}$ ), the resulting NEADW Nd IC should be $-11.2 \pm 0.3$ (this value is calculated assuming an equivalent contribution of the Modified North Atlantic Water and LSW, i.e., 1/6 each. However, the similar Nd ICs of these 2 water masses imply that different relative contributions would not significantly modify this result). This calculated value is significantly more positive (1.6 $\varepsilon_{\mathrm{Nd}}$ units) than the mean measured value of $-12.8 \pm 0.2$.

[48] A more detailed knowledge of the different water mass contributions to the NEADW formation would be required to address this discrepancy precisely in terms of water mass mixing and $\mathrm{Nd}$ external inputs. Such understanding is not yet available to our knowledge [Swift, 1984; McCartney, 1992; Dickson and Brown, 1994; Hansen and Østerhus, 2000; Fleischmann et al., 2001; Read, 2001]. Neither can this issue be addressed in detail with the present data set, in particular because of the number of water masses involved and the restricted spatial resolution of the sampling. Therefore the above described $\mathrm{Nd}$ IC discrepancy will be discussed considering gross circulation features.

[49] The only water mass involved in the NEADW formation having a Nd IC significantly more positive than that measured in the NEADW is the radiogenic pISOW $\left(\varepsilon_{\mathrm{Nd}}=-8.2 \pm 0.6\right)$. The other water masses involved in the NEADW formation (easternLDW, Modified North Atlantic Water and LSW) have Nd ICs which do not substantially differ from each other, varying from -13.5 to -12.5. The acquisition of the NEADW Nd IC can therefore be considered as resulting from the relative influence of two end-members: on the one hand, the pISOW and, on the other hand, the sum of the other water masses, named here the Unradiogenic Waters.

[50] According to this description, an upper limit for the pISOW contribution to the NEADW formation can be constrained from the $\mathrm{Nd}$ IC data. If we consider that the Unradiogenic Waters are characterized by the most negative Nd IC and the highest $\mathrm{Nd}$ concentration among all the end-member components $\left(\varepsilon_{\mathrm{Nd}}=-13.5\right.$ and $[\mathrm{Nd}]=3.4 \mathrm{ppt}$; see Table 4), and if we set the pISOW Nd IC to its most negative value within the error bar (such assumptions maximize the pISOW contribution), then $16 \%$ pISOW would be required to produce a NEADW with an Nd IC of -12.8 . Such a pISOW contribution is far below what is commonly accepted in the literature, the pISOW (totaling $\sim 2 \mathrm{~Sv}$ ) being considered as one of the main constituents of the NEADW [Hansen and Østerhus, 2000]. This calculation shows that, even when considering an extreme case, water mass mixing cannot account for the observed NEADW Nd IC. This suggests that another source of unradiogenic $\mathrm{Nd}$ is required in the NEADW formation. It is therefore probable that the terrigeneous inputs evidenced at station 3 significantly influence the NEADW Nd signature throughout the Subpolar North Atlantic area.

[51] Unlike the NWABW, the NEADW does not flow along the seafloor, but along the slope ( $\sim 2250 \mathrm{~m}$ depth). Thus the Nd IC of the input material probably ranges from $\varepsilon_{\mathrm{Nd}}=-43$ (characterizing a lower limit for the particulate and dissolved river loads and the aerosols) to $\varepsilon_{\mathrm{Nd}}=-24$ (characterizing surface seafloor sediments in the vicinity of station 3). It was estimated above that pure mixing would yield a $\varepsilon_{\mathrm{Nd}}$ of -11.2 for the NEADW (with a corresponding Nd concentration of $3.0 \pm 0.2 \mathrm{ppt}$ ). Taking a water mass flux of about $6 \mathrm{~Sv}$, the external $\mathrm{Nd}$ flux required to account for the observed NEADW Nd IC $\left(\varepsilon_{\mathrm{Nd}}=-12.8\right)$ ranges between 1.0 and $2.6 \mathrm{~g} \mathrm{~s}^{-1}$ (for $\varepsilon_{\mathrm{a}}=-43$ and -24 , respectively; see equation (2)). These values are roughly half (ranging between 50 and $43 \%$ ) of those calculated for the NWABW. Therefore, as for the NWABW, the external Nd flux probably results 


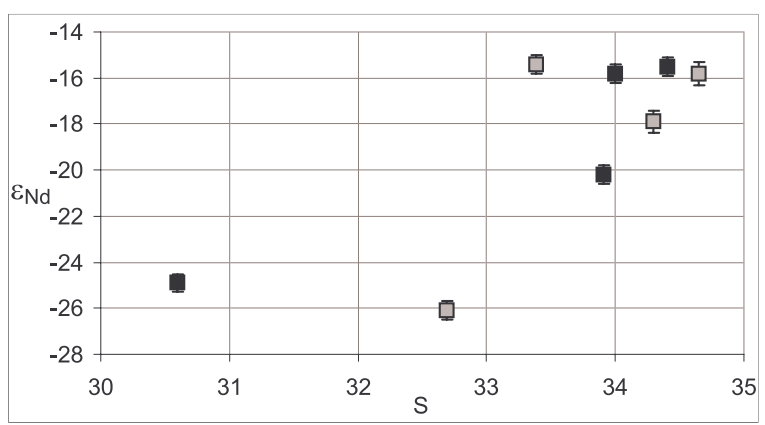

Figure 5. Salinity versus $\varepsilon_{\mathrm{Nd}}$ for seawater samples of the first $125 \mathrm{~m}$ of the Labrador Current, with salinities lower than 34.7. Black and gray squares represent data from the SIGNATURE cruise and data reported by Piepgras and Wasserburg [1987], respectively.

from sediment remobilization, since dissolved river loads and atmospheric deposits have been estimated far below such fluxes.

[52] The origin of the sediments deposited on the slope has not been documented to our knowledge. However, narrow continental shelves, such as that found along the South West Greenland coast (see Figure 1), have been shown to favor sediment transfer from river mouths toward the deep sea [Milliman and Syvitski, 1992]. We will therefore assume that the sediments deposited on the slope are mainly derived from the river particulate discharge along this coast. No river particulate flux compilation is available in this area to our knowledge. However, on the global scale, river particulate $\mathrm{Nd}$ fluxes are on average 800 times greater than dissolved fluxes [Milliman and Meade, 1983; Goldstein and Jacobsen, 1987; Tachikawa et al., 2003]. Applying this ratio to the rivers of the South West Greenland coast leads to a $\mathrm{Nd}$ flux of $134 \mathrm{~g} \mathrm{~s}^{-1}$. The remobilization of only 0.7 to $1.9 \%$ of this discharge would account for the Nd flux of 1.0 to $2.6 \mathrm{~g} \mathrm{~s}^{-1}$ required to explain the NEADW Nd $\mathrm{IC}$, for $\varepsilon_{\mathrm{a}}=-43$ and -24 , respectively.

[53] As previously, these calculations are based on numerous assumptions and need to be considered cautiously. However, they strongly suggest that the NEADW Nd IC is significantly influenced by interactions with sediments deposited on the slope of the South West Greenland margin. This influence would then be almost uniformly redistributed over the entire studied area. This point contrasts with the NWABW Nd IC variations which occur successively along its flow. This underlines the different circulation features of these two water masses, the NWABW being restricted to the Deep Western Boundary Current, whereas the NEADW is widely involved in deep recirculation loops on both sides of the Mid Atlantic Ridge.

[54] This hypothesis, according to which unradiogenic lithogenic imprints on both NWABW and NEADW occur via sediment/seawater interactions, significantly contrasts with Piepgras and Wasserburg's [1987] hypothesis according to which the negative $\mathrm{Nd}$ signature of the bottom and deep Labrador Sea Water masses could result from deep convection of unradiogenic surface waters originating from the Labrador Current and Baffin Bay.

[55] In the absence of other fluxes, such Nd input (1.0 to $2.6 \mathrm{~g} \mathrm{~s}^{-1}$ ) would slightly increase the NEADW Nd concentration from $3.0 \pm 0.2 \mathrm{ppt}$ to 3.2 to 3.4 ppt, for $\varepsilon_{\mathrm{a}}=-43$ and -24 , respectively. As for the NWABW such an increase has not been observed, since the average NEADW Nd concentration within the studied area is $2.7 \pm 0.1 \mathrm{ppt}$. This suggests that boundary exchange also affects the NEADW.

\subsection{LSW}

[56] The LSW is characterized by $\varepsilon_{\mathrm{Nd}}=-13.5 \pm$ 0.4 at station 2 (Figure 1, at $1600 \mathrm{~m}$ depth). This sample represents the purest form of LSW that has been sampled here (see its salinity and oxygen extrema in Figure 3). This is consistent with the fact that, among the stations where LSW was sampled, station 2 is the closest to the formation area of this water mass (no LSW sample is available at station 7). At station 6, located at the exit of the studied area, the LSW has an $\varepsilon_{\mathrm{Nd}}$ of $-13.9 \pm$ 0.4 , identical to the station 2 value given the uncertainty of measurement. In fact, Figure 4 shows that LSW displays a homogeneous horizontal Nd IC distribution (variation range of $1.3 \varepsilon_{\mathrm{Nd}}$ units over the entire studied area). Such homogeneity probably results from the rapid transport of this water mass within the North Atlantic Subpolar Gyre.

[57] The LSW is formed by deep convection in the Labrador Sea from the overlying waters, the SPMW (Figure 2) [Talley and McCartney, 1982]. The acquisition of the SPMW Nd IC is described in detail in a previous work [Lacan and Jeandel, 2004c], based on data obtained from the same cruise. We concluded that the SPMW Nd IC results from the mixing of North Atlantic Central Water (warm and saline waters of subtropical origin, $\left.\varepsilon_{\mathrm{Nd}} \approx-10.2\right)$ and Subarctic Intermediate Water 


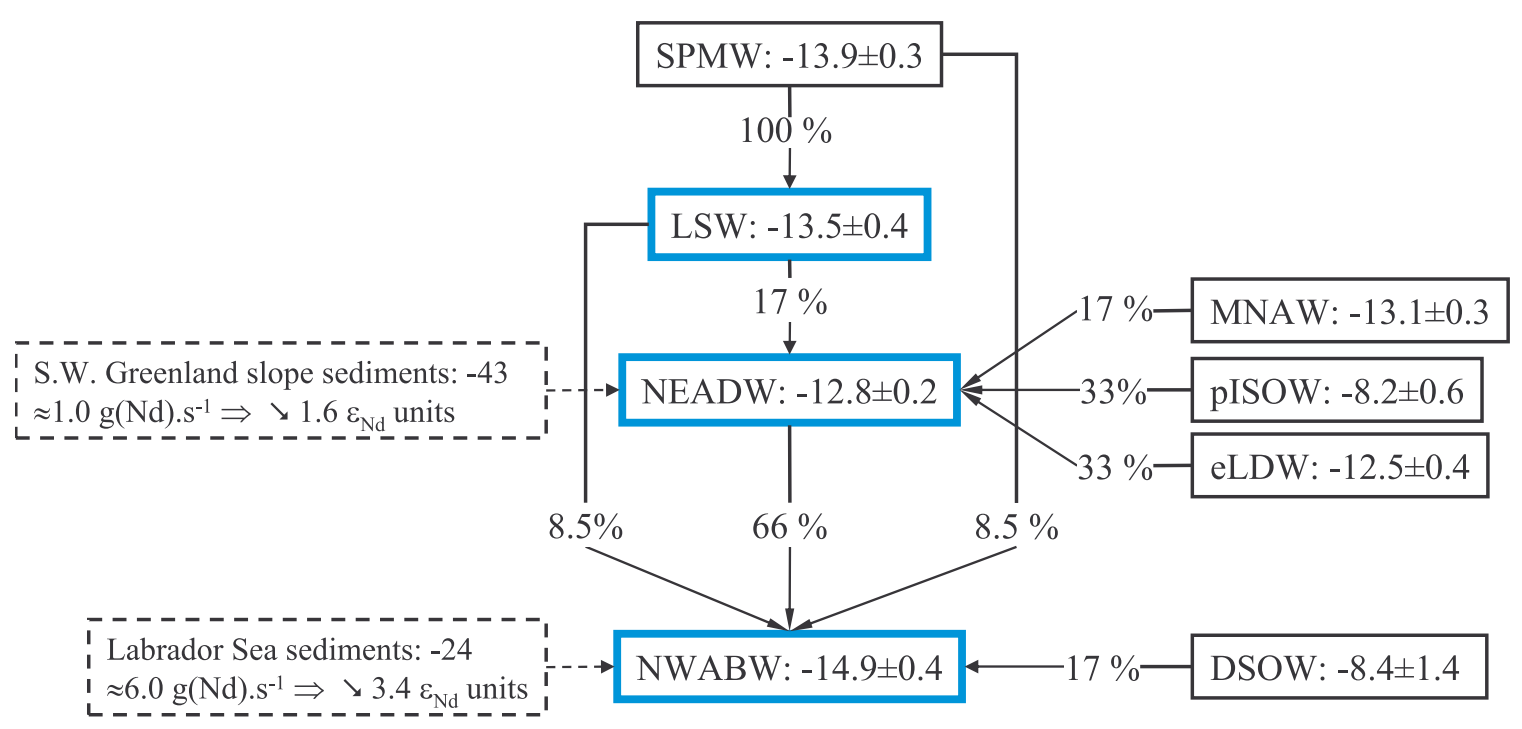

Figure 6. Summary diagram of the Nd IC acquisition of the three proto-NADW layers (LSW, NEADW, and NWABW, identified by the blue frames). The Nd IC of the water masses are indicated. The estimated relative contributions of the source waters are reported. Lithogenic inputs are described in the dashed frames, including their Nd IC, the estimated Nd flux, and the consequence of this input on the water mass Nd IC (" " stands for decrease).

(SAIW, a cold and fresh water mass originating from the Labrador current, $\varepsilon_{\mathrm{Nd}} \approx-15.1$ ), within the first $1000 \mathrm{~m}$ of the North Atlantic Subpolar Gyre. The SPMW Nd IC at station 2 is $\varepsilon_{\mathrm{Nd}}=$ $-13.9 \pm 0.2$ (see Table 4). This value is equivalent to that of the LSW at the same station, clearly suggesting that the LSW acquires its $\mathrm{Nd}$ IC from the SPMW from which it is formed, and that no mechanism other than convection needs to be invoked. It can therefore be concluded that the LSW Nd IC directly reflects that of the overlying SPMW, which itself results from the two endmember mixing of North Atlantic Central Water and SAIW.

[58] The unradiogenic SAIW signature has been hypothesized to result from the very unradiogenic signature of the Labrador Current Water, $\varepsilon_{\mathrm{Nd}} \approx$ -17 (value calculated from Labrador Current samples with $33<\mathrm{S}<34.7$ [Lacan and Jeandel, 2004c]). The Nd IC of seawater samples taken within the Labrador Current are represented as a function of salinity in Figure 5. The fact that the lowest $\varepsilon_{\mathrm{Nd}}$ values correspond to the lowest salinities $\mathrm{S}$ is consistent with Piepgras and Wasserburg's [1987] hypothesis according to which the unradiogenic signature of the Labrador Current could be due to fresh water runoff from the Canadian Shield. Therefore the unradiogenic component of the LSW could ultimately be linked to these unradiogenic lithogenic inputs. However, this hypothesis needs to be confirmed by a better documentation of the links between LSW and SAIW.

\subsection{Proto-NADW}

[59] Figure 6 summarizes the Nd IC acquisition of the three proto-NADW layers, through water mass mixing and lithogenic inputs. Considering the $\mathrm{Nd}$ IC and the concentration of these three layers at station 6 (which characterizes the water masses heading southward from the Subpolar North Atlantic) and their relative fluxes (LSW: $\varepsilon_{\mathrm{Nd}}-13.9 \pm$ $0.4,[\mathrm{Nd}]=2.5 \pm 0.2 \mathrm{ppt}, 4 \mathrm{~Sv}$; NEADW: $\varepsilon_{\mathrm{Nd}}$ $-13.2 \pm 0.4,[\mathrm{Nd}]=2.6 \pm 0.2 \mathrm{ppt}, 6 \mathrm{~Sv}$; NWABW: $\varepsilon_{\mathrm{Nd}}-14.5 \pm 0.4,[\mathrm{Nd}]=2.8 \pm 0.2 \mathrm{ppt}$, concentration from Piepgras and Wasserburg [1987], $6 \mathrm{~Sv}$ ) the average proto-NADW Nd IC is $\varepsilon_{\mathrm{Nd}}=-13.9 \pm$ 0.2 (a $20 \%$ uncertainty has been ascribed to the water mass fluxes). This value conforms closely to that of $-13.5 \pm 0.5$ characterizing the mature NADW in the subtropical North Atlantic Ocean (see compilation by von Blanckenburg [1999]). This implies that the NADW Nd IC acquisition is almost totally completed within the Subpolar North Atlantic (north of $50^{\circ} \mathrm{N}$ ), as already underlined by Piepgras and Wasserburg [1987].

[60] South of this region, the influence of the westernLDW $\left(\varepsilon_{\mathrm{Nd}} \approx-13.5\right)$ on the LowerNADW and that of the Mediterranean Outflow Water 
$\left(\varepsilon_{\mathrm{Nd}} \approx-9.4\right)$ on the UpperNADW do not significantly modify the signature of these waters masses [Piepgras and Wasserburg, 1987; Spivack and Wasserburg, 1988]. Further south, the signatures of these layers increase progressively as the result of progressive mixings with Antarctic Intermediate Water (AAIW, $\varepsilon_{\mathrm{Nd}} \approx-8.2$ ) and Antarctic Bottom Water $\left(\varepsilon_{\mathrm{Nd}} \approx-8.5\right)$ [Piepgras and Wasserburg, 1987; Jeandel, 1993]. On the other hand, the MiddleNADW Nd signature acquired in the Subpolar North Atlantic remains almost unchanged as far south as $40^{\circ} \mathrm{S}\left(\varepsilon_{\mathrm{Nd}}=-12.5 \pm 0.5\right.$ [Jeandel, 1993]).

\section{Summary and Conclusion}

[61] The NWABW, which constitutes the protolower-NADW off Flemish Cap, seems to acquire its Nd IC as follows. The mixing of $\approx^{1 / 2}$ DSOW $\left(\varepsilon_{\mathrm{Nd}} \approx-8.4\right), \approx^{1 / 4} \operatorname{LSW}\left(\varepsilon_{\mathrm{Nd}} \approx-13.5\right)$ and $\approx^{1 / 4}$ SPMW $\left(\varepsilon_{\mathrm{Nd}} \approx-13.9\right)$ produce the NWABW found at Cape Farewell, characterized by $\varepsilon_{\mathrm{Nd}} \approx-10.5$ (note that the end-member $\mathrm{Nd}$ concentrations need to be taken into account to calculate this value). The NWABW Nd IC decrease observed along the southwest Greenland margin (from $\varepsilon_{\mathrm{Nd}}=-10.5$ to -14.9 ) is explained to a small extent ( $1 \varepsilon_{\mathrm{Nd}}$ unit) by a significant mixing with the NEADW and to a greater extent (3.4 $\varepsilon_{\mathrm{Nd}}$ units) by sediment remobilization along the margin.

[62] Our understanding of the complex formation of the NEADW (proto-middle-NADW), in terms of water masses, is still insufficient to address in finer detail the acquisition of its Nd IC. However, considering gross circulation features, with regard to the Nd IC, the NEADW formation can be understood as resulting from the relative influence of two end-members: on the one hand, the pISOW $\left(\varepsilon_{\mathrm{Nd}}=-8.2\right)$ and, on the other hand, the sum of the other water masses involved (easternLDW, LSW and Modified North Atlantic Water, characterized by similar Nd IC, $-13.5<\varepsilon_{\mathrm{Nd}}<-12.5$, named here Unradiogenic Waters). Such mixing would lead to a water mass characterized by $\varepsilon_{\mathrm{Nd}} \approx$ -11.2. External Nd fluxes from sediments deposited on the South West Greenland slope, whose influence would be actively redistributed throughout the North Atlantic Subpolar gyre, would significantly decrease the NEADW Nd IC, from -11.2 to -12.8 .

[63] The LSW (proto-upper-NADW) probably acquires its $\mathrm{Nd}$ IC $\left(\varepsilon_{\mathrm{Nd}}=-13.5 \pm 0.4\right)$ directly from the SPMW from which it is formed by deep convection. The SPMW Nd signature has been suggested to result from the mixing of North Atlantic Central Water $\left(\varepsilon_{\mathrm{Nd}} \approx-10.2\right)$ and SAIW $\left(\varepsilon_{\mathrm{Nd}} \approx-15.1\right.$ [Lacan and Jeandel, 2004c]). The unradiogenic signature of the SAIW could itself result from the very unradiogenic signature of the Labrador Current Water $\left(\varepsilon_{\mathrm{Nd}} \approx-17\right)$, which itself probably reflects lithogenic inputs via fresh water runoff from the Canadian Shield. A better documentation of the SAIW and Labrador Current Water would be required to relate the LSW $\mathrm{Nd}$ IC to its ultimate unradiogenic lithogenic sources.

[64] This new set of Nd IC data, characterized by a significantly better spatial resolution within the North Atlantic Subpolar gyre than the pioneer work of Piepgras and Wasserburg [1987], provides evidence that the three NADW layers acquire their $\mathrm{Nd}$ signatures in different ways. In the three cases, distinct water mass mixings derived from source waters with very diverse Nd IC (ranging from -17 for the Labrador Current Water to -8.2 for the pISOW), and distinct lithogenic inputs, characterized by very diverse Nd IC (ranging from -43 for the South West Greenland margin to +7 for the Greenland-Scotland gap [Lacan and Jeandel, 2004b]), are involved.

[65] In the three cases and especially for the NEADW, a better understanding of the water mass formations, in terms of water mass mixing, would have been necessary to fully exploit the $\mathrm{Nd}$ IC data. Although somewhat neglected in comparison with more dynamic approaches nowadays, the study of water mass distributions and mixings is essential for the use of many geochemical tracers and needs to be more intensively developed.

[66] Lithogenic inputs play a very significant role in the acquisition of the NADW Nd IC. Up to now, unradiogenic lithogenic sources derived from the Greenland and Canadian shield areas have been put forward to explain the unradiogenic signature of the NADW [e.g., Piepgras and Wasserburg, 1987; von Blanckenburg and Nägler, 2001]. The present data set gives evidence that the unradiogenic lithogenic inputs affecting the NWABW and NEADW occur along the Greenland margin and suggests no direct contribution from the Canadian margin. On the other hand, the LSW Nd IC seems to receive lithogenic inputs from the Baffin Bay and the Labrador margins, via contributions of Labrador 
Current Water and SAIW to the LSW formation (no contribution from the South West Greenland margin was detected in that case).

[67] The data obtained during the SIGNATURE cruise [Lacan and Jeandel, 2004a, 2004b, 2004c; this work] underlines that, even though these unradiogenic sources dominate the lithogenic imprint on the NADW, radiogenic lithogenic inputs occurring over the Greenland Scotland ridge are also very significant (increasing the DSOW and ISOW Nd IC by $\sim 2.5$ and $\sim 1.8 \varepsilon_{\mathrm{Nd}}$ units, respectively). Therefore the total lithogenic imprint on the NADW Nd IC, in its formation area, should be considered as resulting from the sum of unradiogenic and radiogenic sources.

[68] Flux calculations firmly suggest that except for the LSW, all the documented lithogenic inputs (affecting the NWABW, NEADW, DSOW and ISOW) occurred via sediment remobilization. In the case of the NWABW and NEADW, the sediment/seawater interactions evidenced along the South West Greenland margin seem to involve both sediment remobilization and $\mathrm{Nd}$ removal from seawater to the sediments. This process, named boundary exchange [Lacan and Jeandel, 2005], is invoked in order to explain the significant $\mathrm{Nd}$ IC variations in the absence of significant $\mathrm{Nd}$ concentration variations.

[69] The present study of the NADW Nd IC acquisition provides significant new constraints on water mass circulation and terrigeneous inputs involved in the NADW formation. In addition it should allow more precise interpretations of paleoceanographic Nd IC records: past variations of the NADW Nd IC could be interpreted taking into account the distinct histories of the three NADW layers, including distinct water mass mixings and distinct lithogenic inputs.

\section{Acknowledgments}

[70] We are grateful to S. Goldstein for his outstanding work as a reviewer. His contribution greatly helped to improve the quality of this article. We also thank an anonymous reviewer. M. Roy Barman is thanked for having carried out the sampling and onboard preconcentration and for his help with the analytical work. We are grateful to M. Souhaut and P. Brunet for their help with the analytical work. We thank the captain and crew of the R/V Marion Dufresne (IPEV) and J. C. Turon and L. Labeyrie, the chief scientists, for their continuous assistance during sampling time. We thank V. McBride for correcting the English. This work was supported by the French national program on climate (PNED/INSU) and the French Polar Institute (IPEV).

\section{References}

Albarède, F., and S. Goldstein (1992), A world map of Nd isotopes in seafloor ferromanganese deposits, Geology, 20, $761-763$.

Amakawa, H., Y. Nozaki, D. S. Alibo, J. Zhang, K. Fukugawa, and H. Nagai (2004), Neodymium isotopic variations in Northwest Pacific waters, Geochim. Cosmochim. Acta, 68, $715-727$.

Carter, S. J., and M. E. Raymo (1999), Sedimentological and mineralogical control of multisensor track data at sites 981 and 984, Proc. Ocean Drill. Program, Sci. Results, 162, 247-257.

Dickson, R. R., and J. Brown (1994), The production of North Atlantic Deep Waters: Sources, rates, and pathways, J. Geophys. Res., 99, 12,319-12,341.

Duce, R. A., et al. (1991), The atmospheric input of trace species to the world ocean, Global Biogeochem. Cycles, 5, 193-259.

Elderfield, H. (1988), The oceanic chemistry of the rare earth elements, Philos. Trans. R. Soc. London, Ser. A, 325, $105-$ 106.

Fleischmann, U., H. Hildebrandt, A. Putzka, and R. Bayer (2001), Transport of newly ventilated deep water from the Iceland Basin to the Westeuropean Basin, Deep Sea Res., Part I, 48, 1793-1819.

Frank, M., N. Whiteley, S. Kasten, J. R. Hein, and K. O’Nions (2002), North Atlantic Deep Water export to the Southern Ocean over the past $14 \mathrm{Myr}$ : Evidence from $\mathrm{Nd}$ and $\mathrm{Pb}$ isotopes in ferromanganese crusts, Paleoceanography, 17(2), 1022, doi:10.1029/2000PA000606.

Goldstein, S. L., and S. R. Hemming (2003), Long lived isotopic tracers in oceanography, paleoceanography, and ice sheet dynamics, in Treatise on Geochemistry, edited by H. Elderfield, chap. 6.17, pp. 453-489, Elsevier, New York.

Goldstein, S. L., and S. B. Jacobsen (1987), The Nd and Sr isotopic systematics of river-water dissolved material: Implications for the sources of $\mathrm{Nd}$ and $\mathrm{Sr}$ in the seawater, Chem. Geol., 66, 245-272.

Hansen, B., and S. Østerhus (2000), North Atlantic-Nordic Seas exchanges, Prog. Oceanogr., 45, 109-208.

Innocent, C., N. Fagel, R. Stevenson, and C. Hillaire-Marcel (1997), Sm-Nd signature of modern and late Quaternary sediments from the northwest North Atlantic: Implications for deep current changes since the Last Glacial Maximum, Earth Planet. Sci. Lett., 146, 607-625.

Jacobsen, S. B., and G. J. Wasserburg (1980), Sm-Nd isotopic evolution of chondrites, Earth Planet. Sci. Lett., 50, 139155.

Jeandel, C. (1993), Concentration and isotopic composition of neodymium in the South Atlantic Ocean, Earth Planet. Sci. Lett., 117, 581-591.

Jeandel, C., J. K. Bishop, and A. Zindler(1995), Exchange of Nd and its isotopes between seawater small and large particles in the Sargasso Sea, Geochim. Cosmochim. Acta, 59, 535-547.

Khatiwala, S., R. Fairbanks, and R. W. Houghton (1999), Freshwater sources to the coastal ocean off northeastern North America: Evidence from $\mathrm{H}_{2}^{18} \mathrm{O} / \mathrm{H}_{2}^{16} \mathrm{O}$, J. Geophys. Res., 104, 18,241-18,255.

Lacan, F., and C. Jeandel (2001), Tracing Papua New Guinea imprint on the central Equatorial Pacific Ocean using neo- 
dymium isotopic compositions and rare earth element patterns, Earth Planet. Sci. Lett., 186, 497-512.

Lacan, F., and C. Jeandel (2004a), Denmark Strait water circulation traced by heterogeneity in neodymium isotopic compositions, Deep Sea Res., Part I, 51, 71-82.

Lacan, F., and C. Jeandel (2004b), Neodymium isotopic composition and rare earth element concentrations in the deep and intermediate Nordic Seas: Constraints on the Iceland Scotland Overflow Water signature, Geochem. Geophys. Geosyst., 5, Q11006, doi:10.1029/2004GC000742.

Lacan, F., and C. Jeandel (2004c), Subpolar Mode Water formation traced by neodymium isotopic composition, Geophys. Res. Lett., 31, L14306, doi:10.1029/ 2004 GL019747.

Lacan, F., and C. Jeandel (2005), Neodymium isotopes as a new tool for quantifying exchange fluxes at the continent-ocean interface, Earth Planet. Sci. Lett., 232, $245-257$

McCartney, M. S. (1992), Recirculating components to the deep boundary current of the northern North Atlantic, Prog. Oceanogr., 29, 283-383.

McCartney, M. S., and L. D. Talley (1982), The Subpolar Mode Water of the North Atlantic Ocean, J. Phys. Oceanogr., 51, 1169-1188.

Milliman, J. D., and R. H. Meade (1983), World-wide delivery of river sediment to the oceans, J. Geol., 91, 1-21.

Milliman, J. D., and J. P. M. Syvitski (1992), Geomorphic/ tectonic control of sediment discharge to the ocean: The importance of small mountainous rivers, J. Geol., 100, 525-544.

Piepgras, D. J., and S. B. Jacobsen (1988), The isotopic composition of neodymium in the North Pacific, Geochim. Cosmochim. Acta, 52, 1373-1381.

Piepgras, D. J., and G. J. Wasserburg (1980), Neodymium isotopic variations in seawater, Earth Planet. Sci. Lett., 50, $128-138$

Piepgras, D. J., and G. J. Wasserburg (1987), Rare earth element transport in the western North Atlantic inferred from isotopic observations, Geochim. Cosmochim. Acta, 51, 1257-1271.

Piotrowski, A. M., S. L. Goldstein, S. R. Hemming, and R. G. Fairbanks (2004), Intensification and variability of ocean thermohaline circulation through the last deglaciation, Earth Planet. Sci. Lett., 225, 205-220.

Piotrowski, A. M., S. L. Goldstein, S. R. Hemming, and R. G. Fairbanks (2005), Temporal relationships of carbon cycling and ocean circulation at glacial boundaries, Science, 307, 1933-1938, doi:10.1126/science. 1104883.

Read, J. (2001), CONVEX-91: Water masses and circulation in the Northeast Atlantic subpolar gyre, Prog. Oceanogr., 48, $461-510$

Rhein, M. (2000), Drifters reveal deep circulation, Nature, 407, 30-31.

Rutberg, R. L., S. R. Hemming, and S. L. Goldstein (2000), Reduced North Atlantic Deep Water flux to the glacial
Southern Ocean inferred from neodymium isotope ratios, Nature, 405, 935-938.

Schmitz, W. J. J. (1996), On the World Ocean Circulation, vol. I, 141 pp., Tech. Rep. WHOI-96-03, Woods Hole Oceanogr. Inst., Woods Hole, Mass.

Spivack, A. J., and G. J. Wasserburg (1988), Neodymium isotopic composition of the Mediterranean outflow and the eastern North Atlantic, Geochim. Cosmochim. Acta, 52, 2762-2773.

Staudigel, H., P. Doyle, and A. Zindler (1985), Sr and Nd isotope systematics in fish teeth, Earth Planet. Sci. Lett., $76,45-56$.

Stordal, M. C., and G. J. Wasserburg (1986), Neodymium isotopic study of Baffin Bay water: Sources of REE from very old terranes, Earth Planet. Sci. Lett., 77, 259-272.

Swift, J. H. (1984), The circulation of the Denmark Strait and Iceland-Scotland overflow waters in the North Atlantic, Deep Sea Res., Part A, 31, 1339-1355.

Tachikawa, K., C. Jeandel, and M. Roy-Barman (1999a), A new approach to $\mathrm{Nd}$ residence time in the ocean: The role of atmospheric inputs, Earth Planet. Sci. Lett., 170, $433-$ 446.

Tachikawa, K., C. Jeandel, A. Vangriesheim, and B. Dupré (1999b), Distribution of rare earth elements and neodymium isotopes in suspended particles of the tropical Atlantic Ocean (EUMELI site), Deep Sea Res., Part I, 46, 733-756.

Tachikawa, K., V. Athias, and C. Jeandel (2003), Neodymium budget in the modern ocean and paleo-oceanographic implications, J. Geophys. Res., 108(C8), 3254, doi:10.1029/ 1999JC000285.

Tachikawa, K., M. Roy-Barman, A. Michard, D. Thouron, D. Yeghicheyan, and C. Jeandel (2004), Neodymium isotopes in the Mediterranean Sea: Comparison between seawater and sediment signals, Geochim. Cosmochim. Acta, 68, 3095-3106.

Talley, L. D. (1999), Mode waters in the subpolar North Atlantic in historical data and during the WOCE period, Int. WOCE Newsl., 37, 3-6.

Talley, L. D., and M. S. McCartney (1982), Distribution and circulation of Labrador Sea Water, J. Phys. Oceanogr., 12, 1189-1205.

Taylor, S. R., and S. M. McLennan (1985), The Continental Crust: Its Composition and Evolution. An Examination of the Geological Record Preserved in Sedimentary Rock, 328 pp., Blackwell, Malden, Mass.

Vance, D., and K. Burton (1999), Neodymium isotopes in planktonic foraminifera: A record of the response of continental weathering and ocean circulation rates to climate change, Earth Planet. Sci. Lett., 173, 365-379.

von Blanckenburg, F. (1999), Tracing past ocean circulation?, Science, 286, 1862-1863.

von Blanckenburg, F., and T. F. Nägler (2001), Weathering versus circulation-controlled changes in radiogenic isotope tracer composition of the Labrador Sea and North Atlantic Deep Water, Paleoceanography, 16, 424-434. 